\title{
Strain-specific pathogenicity of putative host-adapted and nonadapted strains of Streptococcus uberis in dairy cattle
}

\author{
R. Tassi, ${ }^{\star} \dagger$ T. N. McNeilly, ${ }^{*}$ J. L. Fitzpatrick, ${ }^{*}$ M. C. Fontaine,${ }^{*}$ D. Reddick, $\ddagger$ C. Ramage,$\ddagger$ M. Lutton, ${ }^{* 1}$ \\ Y. H. Schukken, $\S$ and R. N. Zadoks ${ }^{*}+\S^{2,3}$ \\ *Moredun Research Institute, Pentlands Science Park, Bush Loan, Penicuik EH26 OPZ, United Kingdom \\ †Royal (Dick) School of Veterinary Studies, University of Edinburgh, Easter Bush Veterinary Centre, Roslin EH25 9RG, United Kingdom \\ ¥Moredun Scientific, Pentlands Science Park, Bush Loan, Penicuik EH26 OPZ, United Kingdom \\ §Department of Population Medicine and Diagnostic Sciences, Cornell University, Ithaca, NY 14853
}

\begin{abstract}
Streptococcus uberis is an important cause of intramammary infection in dairy cattle. Strains of Strep. uberis appear to differ in their ability to cause disease based on previous epidemiological studies. We explored the pathogenicity of 2 strains of Strep. uberis, where one strain represented a putatively host-adapted type based on its ability to cause persistent infection and to spread from cow to cow in a lactating herd. This type was part of a clonal complex that is commonly associated with bovine mastitis. The other strain, which was isolated from a transient infection in a single animal in the same herd and did not belong to any known clonal complex, was selected as putatively nonadapted type. Cows (6 per strain) were experimentally challenged in a single hind quarter and the adjacent hind quarter was used as mock challenged control quarter. Both strains showed an equal ability to grow in the milk of challenge animals in vitro. All cows that were challenged with the putatively host-adapted strain developed clinical signs of mastitis, including fever and milk yield depression as well as elevated somatic cell count due to influx of polymorphonuclear leucocytes and lymphocytes. The cytokine response followed a specific order, with an increase in IL-1 $\beta$, IL-6, and IL-8 levels at the time of first SCC elevation, followed by an increase in IL-10, IL-12p40, and tumor necrosis factor- $\alpha$ levels approximately $6 \mathrm{~h}$ later. In 4 of 6 animals, IL-17A was detected in milk between 57 and $168 \mathrm{~h}$ postchallenge. The increase in IL-17A levels coincided with inversion of the prechallenge $\mathrm{CD} 4^{+}$-to- $\mathrm{CD} 8^{+} \mathrm{T}$ lymphocyte ratio,
\end{abstract}

Received February 28, 2013.

Accepted April 29, 2013.

${ }^{1}$ Current address: Liverpool School of Tropical Medicine, Pembroke Place, Liverpool, L3 5QA, UK.

${ }^{2}$ Current address: Institute of Biodiversity, Animal Health and Comparative Medicine, College of Medical, Veterinary and Life Sciences, University of Glasgow, 464 Bearsden Rd., Glasgow G61 1QH, UK.

${ }^{3}$ Corresponding author: ruth.zadoks@moredun.ac.uk which was observed from $96 \mathrm{~h}$ postchallenge. This was followed by normalization of the $\mathrm{CD} 4^{+}$-to- $\mathrm{CD} 8^{+}$ratio due to continued increase of the $\mathrm{CD}^{+}$concentration up to $312 \mathrm{~h}$ postchallenge. Spontaneous resolution of infection was observed in 5 animals and coincided with a measurable IL-17A response in 4 animals, suggesting that IL-17 may be involved in the resolution of intramammary infection. With the exception of minor elevation of IL-8 levels, no clinical, cytological, or immunological response was detected in quarters challenged with the nonadapted strain. The observed strain-specific pathogenicity was consistent across animals, implying that it is determined by pathogen factors rather than host factors.

Key words: mastitis, Streptococcus uberis, lymphocyte, interleukin-17A

\section{INTRODUCTION}

Streptococcus uberis is a major mastitis pathogen in dairy cattle. It is one of the most common causes of clinical and subclinical mastitis in the United Kingdom, New Zealand, and elsewhere (Milne et al., 2002; Zadoks, 2007; Petrovski et al., 2011). Streptococcus uberis causes mastitis in primiparous heifers, dry cows, and lactating cows, and measures to control contagious mastitis have limited effect on the prevalence and incidence of Strep. uberis mastitis (Hill, 1988; Leigh, 1999). For those reasons, Strep. uberis is generally considered an environmental pathogen. However, epidemiological studies indicate that predominant strains of Strep. uberis occur in many herds, suggesting that these strains may be capable of cow-to-cow transmission or that these strains are highly effective at colonizing the bovine mammary gland (Gillespie et al., 1998; Phuektes et al., 2001b; Zadoks et al., 2003). These putatively host-adapted strains are in contrast to other mastitis-causing Strep. uberis strains, which appear to be less suited to the mammary gland environment. Such nonadapted strains are usually isolated sporadically from 1 or 2 animals within 
a herd. Why host-adapted and nonadapted strains exhibit different capacities to colonize the bovine mammary gland is unknown, although it is possible that, in addition to inherent bacterial factors, these strains may induce different host immune responses. Currently, no experimental data exist comparing the pathogenicity of putatively host-adapted and nonadapted Strep. uberis strains or the clinical and immunological host response following intramammary challenge with such strains.

The early host response to Strep. uberis infection is characterized by a relatively slow but massive influx of PMNL in the infected mammary gland. In experimental challenge studies, this influx of PMNL does not generally result in effective reduction in the number of bacteria (Pedersen et al., 2003; Rambeaud et al., 2003; Bannerman et al., 2004a). In one study, Strep. uberis was observed in macrophages after experimental challenge rather than in neutrophils (Thomas et al., 1994), suggesting that macrophages may play a role in bacterial clearance. However, as macrophages from the milk of lactating cows have low killing activity and allow for intracellular replication of Strep. uberis, their role in the protective immune response against Strep. uberis may be limited (Denis et al., 2006). Most experimental challenge studies focus on the early stages of infection, and resolution of infection is rarely described in those studies (Rambeaud et al., 2003; Bannerman et al., 2004a; Harp et al., 2006). In addition, few experimental challenge studies have been used to examine the role of lymphocytes, which are involved in the immune response to IMI (Riollet et al., 2000). In cows with natural IMI due to Streptococcus spp., the level of $\mathrm{CD}^{+}, \mathrm{CD}^{+}$, and $\gamma$ or $\delta$ cells in milk is elevated (Taylor et al., 1997; Soltys and Quinn, 1999). It has been suggested that $\mathrm{CD} 8^{+}$cells, in particular, may play a role in the control of Strep. uberis infection through bactericidal activity (Denis et al., 2011). In addition to the cellular response, the immune response to Strep. uberis involves production of several cytokines, including the proinflammatory cytokines tumor necrosis factor $\alpha$ (TNF- $\alpha)$ and IL-1 $\beta$, the chemoattractant IL-8 (Rambeaud et al., 2003; Bannerman et al., 2004a), the anti-inflammatory cytokine IL-10, and $\mathrm{T}$ helper type 1 (Th1)-associated cytokines, such as IFN- $\gamma$ and IL12 (Bannerman et al., 2004a). Somatic cells obtained from mammary glands with chronic streptococcal or enterococcal infections had elevated levels of mRNA encoding IL-17A compared with cells from uninfected control quarters (Bruno et al., 2010). Interleukin-17A also modulates the response of mammary epithelial cells to staphylococci in vitro (Bougarn et al., 2011). To date, the IL-17A profile of milk during development or resolution of IMI with Strep. uberis has not been described yet.
The aims of our study were to provide simultaneous characterization of the clinical, bacteriological, and cellular response to intramammary challenge with a putatively host-adapted and a nonadapted strain of Strep. uberis, and to characterize local cytokine profiles during onset and resolution of infection with inclusion of the prototypic member of the IL-17 cytokine family, IL-17A.

\section{MATERIALS AND METHODS}

\section{Challenge Strains}

Challenge strains of Strep. uberis were selected using epidemiological, clinical, and molecular data. Strain FSL Z1-048 was selected to represent characteristics of putatively host-adapted Strep. uberis, such as chronicity of infection and contagious transmission within a herd, whereas strain FSL Z1-124 was selected to represent characteristics of nonadapted Strep. uberis, such as transient infection and environmental origin (Zadoks et al., 2003; Zadoks, 2007). The 2 strains were originally isolated from the same herd during the same time period so that differences in clinical manifestation and transmission could not be attributed to differences in management conditions on the farm of origin. Strain FSL Z1-048 was isolated from several cases of persistent subclinical mastitis (median duration $=50 \mathrm{~d}$ ) in lactating cows during a mastitis outbreak, whereas FSL Z1-124 belonged to a strain that was isolated from a single case of mastitis of short duration (observed duration $<9 \mathrm{~d}$ ) in a heifer at calving (i.e., without prior exposure to the milking machine; Zadoks et al., 2003). The strains are genetically distinct by a large number of open-reading frames (Lang et al., 2009). Based on multilocus sequence typing, FSL Z1-048 belongs to sequence type 385 and clonal complex 143, a clonal complex that is predominantly associated with subclinical mastitis (Tomita et al., 2008). Strain FSL Z1-124 belongs to ST383, which is a singleton (i.e., it is not associated with a known clonal complex; Lang et al., 2009; http://pubmlst.org/suberis/).

\section{Growth of Challenge Strains in Milk}

The ability of both challenge strains to grow in milk was assessed in vitro, using milk from the animals enrolled in the challenge study (see Challenge Study Design section). The bacterial inoculum for the in vitro growth experiment was prepared from stock cultures of FSL Z1-048 and FSL Z1-124 stored at $-80^{\circ} \mathrm{C}$. Stock cultures were thawed, plated on $5 \%$ horse blood agar (E\&O Laboratories, Bonnybridge, UK) and incubated overnight at $37^{\circ} \mathrm{C}$ to check for viability and purity. Ap- 
proximately 5 colonies per strain were then inoculated into $15 \mathrm{~mL}$ of brain heart infusion broth (Difco, Cambridge, UK) and incubated for $20 \mathrm{~h}$ at $37^{\circ} \mathrm{C}$. Bacterial concentration of the incubated broth was determined by viable count method as detailed at the end of this section, whereas the remainder was stored at $4^{\circ} \mathrm{C}$, a temperature that does not permit growth of Strep. uberis (Dogan and Boor, 2004). The next day, stored broth cultures were serially diluted in sterile PBS to obtain the target inoculum concentration of 1,000 cfu/ $\mathrm{mL}$ for each strain. The actual inoculum concentration was checked by viable count method.

To assess the growth potential of challenge strains in milk from study animals, milk was collected aseptically from both hind quarters of each animal just before milking, $1 \mathrm{~d}$ before experimental challenge. Milk samples were kept on ice and transported to the laboratory for inoculation of culture plates within $1 \mathrm{~h}$ of sample collection. For each cow, equal volumes of milk from both hind quarters were comingled, and $10 \mu \mathrm{L}$ were plated onto horse blood agar (E\&O Laboratories) for overnight incubation at $37^{\circ} \mathrm{C}$ to check for the absence of contaminants and pathogens associated with IMI. For each cow, one 14-mL aliquot of comingled milk was then inoculated with strain FSL Z1-048 and 1 aliquot of $14 \mathrm{~mL}$ with FSL Z1-124, using approximately 1,000 cfu of Strep. uberis in $1 \mathrm{~mL}$ of PBS (see Intramammary Challenge section). Inoculated milk was incubated for $24 \mathrm{~h}$ at $37^{\circ} \mathrm{C}$ under shaking $(200 \mathrm{rpm})$. At 0,3 , 6,12 , and $24 \mathrm{~h}$ post inoculation, $100 \mu \mathrm{L}$ of milk were taken off and bacterial concentration was determined by viable counting, that is, 1:10 serial dilution series were prepared in sterile PBS and three $10-\mu \mathrm{L}$ drops per dilution were plated onto horse blood agar plates (E\&O Laboratories) and incubated overnight at $37^{\circ} \mathrm{C}$. Colonies were counted when they were in the range of 5 to 50 cfu per spot, and the bacterial concentration for each time point $(\mathrm{cfu} / \mathrm{mL})$ was calculated based on average colony counts for the appropriate dilution.

\section{Challenge Study Design}

Twelve nonpregnant, clinically healthy Holstein cows with no history of clinical mastitis were used in this experiment. Cows were in midlactation (60-160 DIM on the day of challenge) and parity ranged from 1 to 5. Composite SCC as measured during 4 weekly milk recordings was $<100,000$ cells $/ \mathrm{mL}$ at the time of purchase, with the exception of 1 animal that had composite SCC of 152,000 cells/mL. This animal tested positive for CNS in 1 hind quarter and the culture negative contralateral quarter was used as challenge quarter. On the day before challenge, quarter level SCC was $<100,000$ cells $/ \mathrm{mL}$ for 22 of 24 challenge quarters and between 100,000 and 200,000 cells/mL for the remaining 2 quarters. Quarter milk samples from all animals were negative for Strep. uberis before purchase and between purchase and challenge. Challenge studies were conducted using 4 cows at a time, with cows housed in loose housing (group 1) or cubicles (groups 2 and 3 ), with straw bedding in both housing systems. Cows had access to water and grass silage ad libitum and concentrate was fed 3 times a day based on milk yield. Cows were milked twice a day, at 0600 and $1500 \mathrm{~h}$, using a dedicated milking unit for each cow. After each milking, all teats were dipped in iodine-based teat disinfectant. Each cow was challenged with Strep. uberis in 1 hind quarter and mock challenged with PBS in the other hind quarter as detailed in the next section. In each group of 4 animals, strain-quarter combinations (FSL Z1-048/right hind, FSL Z1-124/ right hind, FSL Z1-048/left hind, FSL Z1-124/ left hind) were allocated to individual cows based on random sampling without replacement. Clinical data and samples were collected for $14 \mathrm{~d}$ postchallenge. All experiments were conducted at the Moredun Research Institute (Penicuik, UK) with approval of the Institute's Experiments and Ethical Review Committee in accordance with the Animals (Scientific Procedures) Act 1986.

\section{Intramammary Challenge}

The bacterial inoculum for challenge experiments was prepared as described for the growth curve experiment, with the exception that the target concentration for animal challenge was $100 \mathrm{cfu} / \mathrm{mL}$. Challenge doses were kept at $4^{\circ} \mathrm{C}$ (in the laboratory) or on ice (in the milking parlor) until infusion. On the day of challenge, cows were milked per normal procedures, including the use of postmilking teat disinfection. Subsequently, teat ends were disinfected by scrubbing with cotton wool swabs with $70 \%$ (vol/vol) ethanol. Two milliliters of inoculum preparation (target dose $=200 \mathrm{cfu} /$ quarter) were infused into each challenge quarter via a J-12 teat infusion cannula (Jorgens Laboratories, Loveland, CO). Control quarters were mock challenged by infusion of 2 $\mathrm{mL}$ of sterile PBS. After infusion, teats were dipped in postmilking teat disinfectant and cows were returned from the milking parlor to their pen, as per normal procedures. The actual challenge dose for each strain in each challenge round was determined by viable count method using spare doses of the inoculum preparation.

\section{Sample and Data Collection}

Milk samples and clinical data were collected at various time points following infusion. For the first $48 \mathrm{~h}$, clinical data and milk samples for SCC determination, 
bacterial culture, and cytokine ELISA were collected every $6 \mathrm{~h}$. From 2 to $11 \mathrm{~d}$ postchallenge, milk samples for SCC and culture were collected twice a day, and from 11 to $13 \mathrm{~d}$ postchallenge once a day. On d 3 and 4 postchallenge, milk samples for cytokine ELISA were collected twice a day, and on d 5 through 7 postchallenge samples were collected once a day. Additional milk samples for cytokine ELISA were collected on d 10 and 13 postchallenge. Samples for flow cytometric analysis of lymphocyte populations were collected on d 1, 2, 4, 6, 8, 10, and 13 postchallenge. Clinical scores were assigned to each quarter and cow based on a 3-point scale where $0=$ no clinical signs; $1=$ milk alteration only, such as alteration of color or presence of clots; $2=$ local signs, such as redness of the udder, pain on palpation, or swelling; 3 = systemic signs, for example, fever, anorexia or lethargy. Quarter milk samples for bacteriological analysis were collected using aseptic technique (National Mastitis Council, 1999) and stored on ice until refrigeration at $4^{\circ} \mathrm{C}$. Separate receptacles were used to collect quarter milk samples for SCC measurement, cytokine ELISA, and flow cytometry.

\section{Bacteriological Analysis}

Qualitative and quantitative bacteriological analysis was performed by Moredun Scientific Ltd. (Penicuik, UK). For qualitative analysis, $10 \mu \mathrm{L}$ of milk from each quarter (challenged, mock-challenged, and unchallenged quarters) were plated on horse blood agar (E\&O Laboratories) and incubated at $37^{\circ} \mathrm{C}$ for $24 \mathrm{~h}$. Colonies were identified based on morphology and standard biochemical tests (Gram staining, catalase test, esculin splitting; National Mastitis Council, 1999). For quantitative analysis, milk samples from challenged quarters were serially diluted with 10 -fold dilutions from neat to $10^{-8}$ in sterile PBS. Triplicate $10-\mu \mathrm{L}$ aliquots of each dilution were spotted on blood agar plates (E\&O Laboratories), allowed to air dry, and incubated overnight at $37^{\circ} \mathrm{C}$. Colonies with morphology consistent with Strep. uberis were counted, if possible in the range of 5 to $50 \mathrm{cfu}$ per spot, and the bacterial concentration in milk $(\mathrm{cfu} / \mathrm{mL}$ ) was calculated based on average colony counts for appropriate dilutions.

\section{Molecular Typing}

Polymerase chain reaction and pulsed-field gel electrophoresis (PFGE) were used to confirm species and strain identity, respectively. Where possible, 3 Strep. uberis isolates from each challenged quarter were analyzed (i.e., 1 isolate each from the first and last positive sample postchallenge and from the time point with peak bacterial shedding). A total of 18 isolates were analyzed from the 6 cows challenged with strain FSL Z1-048, with each cow represented by 3 isolates. Five isolates, representing 3 cows, were available from animals challenged with strain FSL Z1-124. Species identity of isolates was confirmed using PCR primers and parameter settings as described by Phuektes et al. (2001a). For PFGE of confirmed Strep. uberis isolates, $1.5 \mathrm{~mL}$ of overnight culture in brain heart infusion was centrifuged for $10 \mathrm{~min}$ at $13,400 \times \mathrm{g}$ at room temperature. Supernatants were discarded and cell pellets were resuspended in $0.5 \mathrm{~mL}$ of Tris-EDTA (TE) buffer (10 m $M$ Tris hydrochloric acid, $1 \mathrm{~m} M$ EDTA, pH 8). Bacterial suspensions were mixed with $2 \%$ (wt/ vol) low-melting-point agarose (BioRad Laboratories, Hertfordshire, UK) in TE buffer at $56^{\circ} \mathrm{C}$. Plugs were allowed to solidify and incubated overnight at $37^{\circ} \mathrm{C}$ in 2 $\mathrm{mL}$ of TE buffer containing $4 \mathrm{mg} / \mathrm{mL}$ lysozyme (SigmaAldrich, Dorset, UK). Supernatants were removed and plugs were incubated for $48 \mathrm{~h}$ at $56^{\circ} \mathrm{C}$ in $2 \mathrm{~mL}$ of $0.5 \mathrm{M}$ of EDTA containing $2 \mathrm{mg} / \mathrm{mL}$ of proteinase K (SigmaAldrich) and 1\% wt/vol N-laurylsarcosine sodium. Proteinase $\mathrm{K}$ solution was removed and plugs were washed for $1 \mathrm{~h}$ in $36 \mathrm{~mL}$ of TE buffer under shaking (100 $\mathrm{rpm})$. Washing was repeated 6 times. Plugs were preincubated in $300 \mu \mathrm{L}$ of reaction buffer containing (1\% $\mathrm{wt} / \mathrm{vol}) \mathrm{BSA}, 20 \mathrm{~m} M$ Tris-acetate, $50 \mathrm{~m} M$ potassium acetate, $10 \mathrm{~m} M$ magnesium acetate, and $1 \mathrm{~m} M$ dithiothreitol ( $\mathrm{pH}$ 7.9) for $1 \mathrm{~h}$ at $37^{\circ} \mathrm{C}$. Reaction buffer was removed, $100 \mu \mathrm{L}$ of enzyme buffer containing 30 units of restriction enzyme SmaI (New England Biolabs, Hitchin, UK) was added to each plug, and plugs were incubated overnight at $25^{\circ} \mathrm{C}$. Plugs were then inserted into a gel prepared from $1 \%$ (wt/vol) PFGE-certified agarose (BioRad Laboratories) in $0.5 \times$ Tris-borateEDTA (TBE) buffer ( $45 \mathrm{~m} M$ Tris base, $45 \mathrm{~m} M$ boric acid, $1 \mathrm{~m} M$ EDTA, $\mathrm{pH}$ 8.0). Restriction fragments were separated by PFGE at $14^{\circ} \mathrm{C}$ for $24 \mathrm{~h}$, with initial switch time $3 \mathrm{~s}$, final switch time $55 \mathrm{~s}$, and linear ramp using a CHEF mapper (BioRad Laboratories). Gels were stained with SYBR Gold stain (Invitrogen, Paisley, UK) according manufacturer's instruction, rinsed, and photographed under UV light.

\section{Somatic Cell Counting and Flow Cytometry}

Approximately $25 \mathrm{~mL}$ of milk were collected in plastic vials preloaded with preservative and shipped to National Milk Laboratories (Hillington Park, Glasgow, UK) for determination of SCC by Fossomatic milk cell counter (Foss Electronic, Hillerød, Denmark). For flow cytometry, approximately $50 \mathrm{~mL}$ of milk per quarter was collected in plastic Falcon vials (BD Bioscience, Oxford, UK). Milk was kept on ice and transported to the laboratory within $30 \mathrm{~min}$, where it was diluted 
with an equal volume of cold PBS and centrifuged at $800 \times g$ for $20 \mathrm{~min}$. Using a sterile pastette, cell pellets were transferred into $30 \mathrm{~mL}$ of PBS and resuspended. Cell suspensions were filtered through a $70-\mu \mathrm{m}$ cell strainer (BD Bioscience) and centrifuged at $400 \times g$ for 15 min. Supernatants were discarded and cell pellets resuspended in $25 \mathrm{~mL}$ of PBS. Washing was repeated once and pellets were resuspended in $1 \mathrm{~mL}$ of FACS buffer (PBS supplemented with $1 \%$ wt/vol BSA). Ten microliters of cell suspension were stained with an equal volume of trypan blue (Sigma-Aldrich) and viable cell concentration was determined using a microscope cell counting chamber, with cell concentration adjusted to 1 $\times 10^{6}$ cells $/ \mathrm{mL}$. Aliquots of milk cells were labeled with a panel of monoclonal antibodies (Table 1) to identify T-lymphocyte populations and subpopulations (i.e., CD4, CD8, and $\gamma / \delta \mathrm{T}$ cells). Fifty microliters of cell suspension were mixed with $50 \mu \mathrm{L}$ of the appropriate blocking buffer $(20 \% \mathrm{vol} / \mathrm{vol}$ heat-inactivated normal mouse serum in FACS buffer for CD4 or CD8 staining; $20 \% \mathrm{vol} / \mathrm{vol}$ heat-inactivated normal goat serum in FACS buffer for CD3 or $\gamma / \delta$ staining). Samples were incubated for $30 \mathrm{~min}$ at room temperature and subsequently centrifuged at $700 \times g$ for $1 \mathrm{~min}$. Supernatants were discarded and $100 \mu \mathrm{L}$ of antibody diluted with the appropriate buffer ( $10 \% \mathrm{vol} / \mathrm{vol}$ heat-inactivated normal mouse serum in FACS buffer for CD4 or CD8 staining; $10 \% \mathrm{vol} / \mathrm{vol}$ heat-inactivated normal goat serum in FACS buffer for CD3 or $\gamma / \delta$ staining) were added. Samples were incubated for $30 \mathrm{~min}$ at $4^{\circ} \mathrm{C}$. After staining with anti-CD4 or anti-CD8 antibody, cells were washed twice with FACS buffer and once with PBS. Finally, they were resuspended in PBS with $1 \%$ wt/vol paraformaldehyde for $10 \mathrm{~min}$. Cells stained with anti-CD3 or anti- $\gamma / \delta$ antibodies were washed twice with FACS buffer. Then, $100 \mu \mathrm{L}$ of a $1 \mu \mathrm{g} / \mathrm{mL}$ dilution of goat anti-mouse IgG conjugated to Alexa Fluor 488 (Invitrogen) was added and the cells were incubated at $4^{\circ} \mathrm{C}$ for $30 \mathrm{~min}$. After staining, cells were washed and fixed in PBS with paraformaldehyde as described for CD4 and CD8 staining. Cells were acquired with a 2 laser Cyan flow cytometer (Beckman Coulter, High Wycombe, UK). Cell debris was differentiated from cells by means of gating and data were collected for a minimum of 10,000 cells for each sample. Data were analyzed using FlowJo software (Tree Star, Ashland, OR). The lymphocyte population was gated based on forward and side scatter and the percentage of positive cells for each staining was calculated within the lymphocyte gate. Cytocentrifuge preparations of selected samples were prepared using a Shandon Cytospin 4 cytocentrifuge (Thermo Electron Corporation, Milford, MA) and stained using a Reastain Quick-Diff Kit (Reagena, Toivala, Finland) for subsequent differential cell counting. Lymphocyte concentrations were calculated based on SCC and the percentage of lymphocytes as determined by flow cytometry.

\section{Cytokine Measurements}

Milk samples for cytokine measurement were collected in sterile 50-mL plastic Falcon tubes. Skim milk was prepared by centrifuging $50 \mathrm{~mL}$ of milk at $2,800 \times$ $g$ at $4^{\circ} \mathrm{C}$ for $20 \mathrm{~min}$. The fat layer was discarded and the supernatant was transferred to a new 50-mL Falcon tube. Centrifugation was repeated and the supernatant was stored at $-20^{\circ} \mathrm{C}$ until analysis. Microtiter plates (Immunolon 2 HB, Thermo Electron Corporation, Langenselbold, Germany) were coated overnight at $4^{\circ} \mathrm{C}$ with $100 \mu \mathrm{L} /$ well of the appropriate coating antibody (Table 2) diluted in $0.5 \mathrm{M}$ carbonate buffer $(0.5 \mathrm{M}$ $\mathrm{Na}_{2} \mathrm{CO}_{3}, 0.5 \mathrm{M} \mathrm{NaHCO}_{3}, \mathrm{pH} 9.6$ ). Wells were washed

Table 1. Details of mouse monoclonal antibodies used for flow cytometry

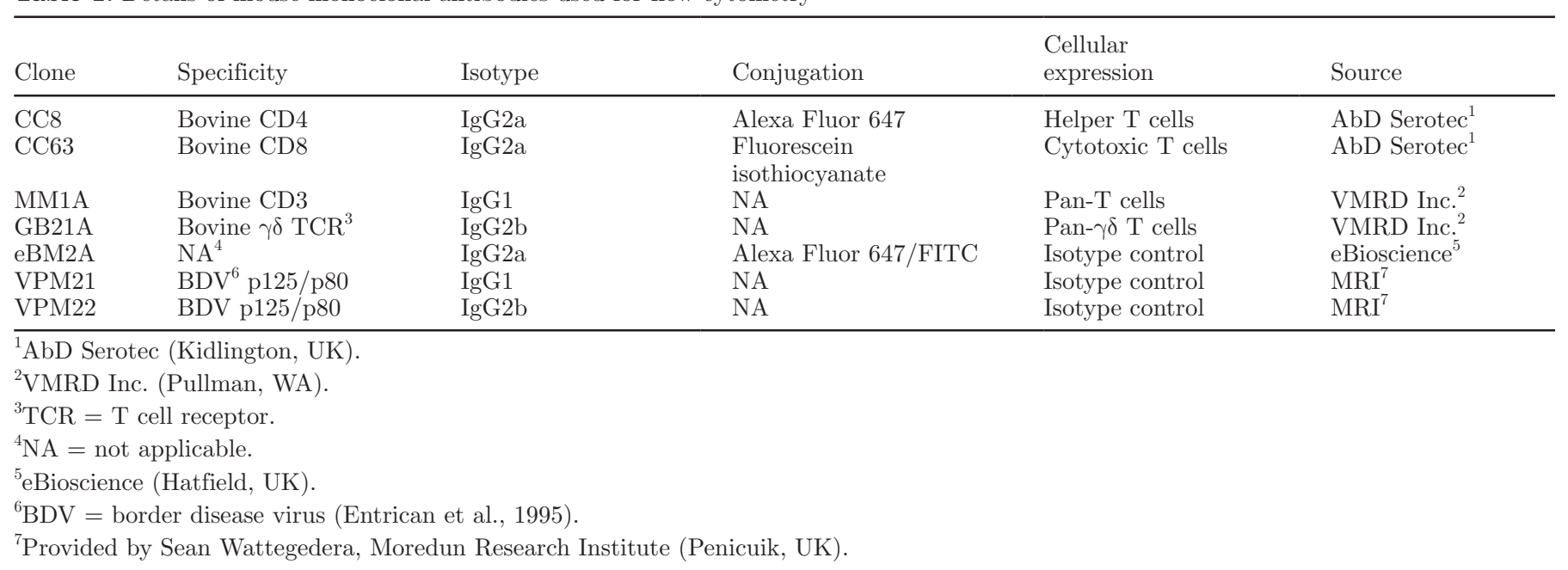


Table 2. Details of antibodies used for cytokine ELISA

\begin{tabular}{|c|c|c|c|c|}
\hline Specificity & Antibody & $\begin{array}{l}\text { Isotype, } \\
\text { species }\end{array}$ & $\begin{array}{l}\text { Concentration } \\
(\mu \mathrm{g} / \mathrm{mL})\end{array}$ & Source \\
\hline IL-1ß coating & Polyclonal & NA, ${ }^{1}$ rabbit & 5 & AbD Serotec ${ }^{2}$ \\
\hline IL-1 $\beta$ detection & Biotinylated polyclonal & NA, rabbit & 1 & AbD Serotec \\
\hline IL-8 coating & $8 \mathrm{M} 6$ & IgG2a, mouse & 5 & AbD Serotec \\
\hline IL-8 secondary & Polyclonal & IgG, rabbit & 2 & AbD Serotec \\
\hline IL-10 coating & CC318 & IgG2b, mouse & 4 & AbD Serotec \\
\hline IL-10 detection & Biotinylated CC230 & IgG1, mouse & 1 & AbD Serotec \\
\hline IL-12p40 coating ${ }^{3}$ & CC301 & IgG2a, mouse & 1 & AbD Serotec \\
\hline IL-12p40 detection ${ }^{3}$ & Biotinylated CC326 & IgG2b, mouse & 2 & AbD Serotec \\
\hline TNF- $\alpha$ coating ${ }^{4}$ & CC327 & IgG2b, mouse & 2 & AbD Serotec \\
\hline TNF- $\alpha$ detection & Biotinylated CC328 & IgG2a, mouse & 1 & AbD Serotec \\
\hline
\end{tabular}

with washing buffer [PBS at pH 7.4 with $0.05 \%$ vol/ vol Tween 20 (Sigma-Aldrich)] and nonspecific binding sites were blocked at room temperature for $1 \mathrm{~h}$ with $300 \mu \mathrm{L} /$ well of PBS containing 3\% (wt/vol) BSA and $0.05 \%$ (vol/vol) Tween 20 (Sigma-Aldrich). Plates were washed again with washing buffer and incubated for $1 \mathrm{~h}$ at room temperature with $100 \mu \mathrm{L} /$ well of skim milk. Each sample was tested in duplicate. When necessary, samples were diluted as appropriate with PBS supplemented with $0.05 \%$ (vol/vol) Tween 20 (SigmaAldrich) and 1\% (wt/vol) BSA (reagent diluent). A standard curve of known cytokine concentrations was assayed for each plate using appropriate standard diluted in reagent diluent. Recombinant bovine standards were used for IL-1 $\beta$ (AbD Serotec, Kidlington, UK), IL-8 (Kingfisher Biotech, Upper Heyford, UK), and TNF- $\alpha$ (R\&D systems, Minneapolis, MN). For IL-10 and IL-12p40, recombinant ovine standards were used (provided by Sean Wattegedera, Moredun Research Institute, Penicuik, UK). Plates were washed with washing buffer and $100 \mu \mathrm{L} /$ well of appropriate detection antibody (Table 2) in reagent diluent were added, followed by incubation for $1 \mathrm{~h}$ at room temperature. For IL-1 $\beta$, IL-10, IL-12p40, and TNF- $\alpha$ plates, 100 $\mu \mathrm{L} /$ well of horseradish peroxidase (HRP)-streptavidin diluted 1:500 in reagent diluent (Sigma-Aldrich) were added, followed by incubation for 45 min at room temperature. Interleukin- 8 plates were incubated with 100 $\mu \mathrm{L} /$ well of HRP-conjugated polyclonal goat antirabbit immunoglobulins (Dako, Ely, UK) diluted 1:1,000 in reagent diluent for $1 \mathrm{~h}$ at room temperature. After incubation with HRP-streptavidin or HRP-conjugated antibody, plates were washed and incubated for $20 \mathrm{~min}$ at room temperature with $100 \mu \mathrm{L}$ per well of $o$-Phenylenediamine dihydrochloride substrate (Sigma-Aldrich). The reaction was stopped with $25 \mu \mathrm{L}$ per well of 2.5 $M$ of $\mathrm{H}_{2} \mathrm{SO}_{4}$ and optical density was measured at 492 nm using a sunrise absorbance reader (Tecan, Theale, UK). Cytokine concentrations in skim milk samples were calculated from the standard curve. Concentrations of IFN- $\gamma$, IL-6, and IL-17A in milk samples were measured with commercial kits (R\&D Systems; Pierce biotechnology, Rockford, IL; and Kingfisher Biotech, respectively) according to the manufacturers' instructions.

\section{Statistical Analysis}

All data were entered into a database and checked for outliers and missing values using SAS 9.2 (SAS Institute Inc., Cary, NC). Outliers were re-evaluated where necessary, but no outliers were removed from the data set. Simple descriptive and graphical analyses were performed for all parameters. Where necessary, transformations were performed to normalize the data (e.g., for SCC and cfu counts). To evaluate the effect of strain and time postinfusion (PI) on any of the measured parameters, a generalized linear mixed model was fit to the data. The general format of the model was

$$
\begin{aligned}
& f(y)=\text { incpt }+ \text { time }+ \text { strain } \\
& + \text { time } \times \text { strain }+ \text { Cow }+ \text { Re },
\end{aligned}
$$

where $f(y)$ is a function of the parameter of interest (i.e., a transformation or identity function, as appropriate); incpt is the intercept; time is the time PI; strain is an indicator variable indicating either FSL Z1-048 or FSL Z1-124; time $\times$ strain is the interaction between time and strain; Cow is a random cow effect; and Re is a complex error term where $\mathrm{R}$ indicates the within quarter correlation of the repeated measures and e indicates a random error term, assumed to be normally distributed with mean 0 and variance $\sigma^{2}$. The model fit 
was assessed using the ratio of the deviance to the remaining degrees of freedom. Least squares means from the models were calculated and used for graphing of the data. Significance testing was done to evaluate the differences between strains over time using contrasts of the least squares means. A Bonferroni correction was used in case of comparisons against prechallenge values in infected and control quarters at multiple time points postchallenge. Statistical significance was declared at $P<0.05$. Postinoculation least squares means values were compared with the preinoculation (Time 0) values, with the exception of lymphocyte concentrations and ratios. The latter were compared between challenge quarters and control quarters within time points to allow for significance testing despite lack of complete data for individual quarters.

\section{RESULTS}

\section{In Vitro Growth of Challenge Strains in Milk}

The ability of strains FSL Z1-048 (putatively hostadapted) and FSL Z1-124 (nonadapted) to grow in fresh milk in vitro was tested using milk samples from 8 individual animals. Results from 1 sample inoculated with strain FSL Z1-048 were discarded because of bacterial contamination of the sample. The actual inoculum dose ranged between 700 and 1,280 cfu of Strep. uberis per sample. Both challenge strains were able to grow in fresh milk in vitro with significantly higher levels of bacterial growth observed with strain FSL Z1-124 compared with strain FSL Z1-048 at 3, 6 , and $12 \mathrm{~h}$ postinoculation (Figure 1A). Strain FSL Z1-124 was first detected at $3 \mathrm{~h}$ postinoculation, with more than half of the milk samples testing positive, whereas strain FSL Z1-048 was first detected in milk at $6 \mathrm{~h}$ postinoculation, with only 1 sample testing positive (Figure 1B). At $24 \mathrm{~h}$ postinoculation, all milk samples tested positive. The maximal bacterial concentration at $24 \mathrm{~h}$ posinoculation did not differ between FSL Z1-048 and FSL Z1-124 (7.68 \pm 0.13 and $6.68 \pm 0.19 \log _{10} \mathrm{cfu} /$ $\mathrm{mL}$ respectively).

\section{Clinical Response}

All 6 cows challenged with Strep. uberis strain FSL Z1-048 developed clinical mastitis. In contrast, none of the 6 cows challenged with strain FSL Z1-124 developed clinical signs of mastitis. Clinical signs were first observed 30 to $48 \mathrm{~h}$ PI (Table 3). The peak in average clinical score $(2.2 \pm 0.4)$ occurred between 48 and $57 \mathrm{~h}$ PI (Figure 2A). Increased rectal temperature was observed in all animals challenged with strain FSL Z1-048. The first increase in rectal temperature was detected between 24 and $72 \mathrm{~h} \mathrm{PI}$ (Table 3 ). The average temperature reached a peak of $40.0 \pm 1.0^{\circ} \mathrm{C}$ at $36 \mathrm{~h} \mathrm{PI}$ (Figure 2B) and remained elevated at 48 and $57 \mathrm{~h}$ PI $(P<0.05)$. At $72 \mathrm{~h}$, average body temperature was not significantly different from prechallenge levels, despite delayed onset of fever in 1 individual (Table 3; Figure 2B). The body temperature of cows challenged with FSL Z1-124 remained at prechallenge level throughout the study. Milk production decreased in all animals challenged with strain FSL Z1-048. Mean production decreased by almost $50 \%$ on the second day PI and remained significantly depressed on d 3 PI $(P<0.05$; Figure 2C). Milk production started to increase again at $\mathrm{d} 4$ PI. No change in milk output was observed in animals challenged with strain FSL Z1-124 (Figure $2 \mathrm{C})$.

\section{Bacterial Culture and Molecular Typing}

Culture of unused doses of the challenge inoculum showed that quarters had been infused with 53 to 712 cfu of strain FSL Z1-048 or 80 to 700 cfu of FSL Z1-124. In the last round of the experiment, the dose of FSL Z1-124 was increased approximately 100-fold, to 14,800 cfu, to determine whether a high inoculum dose would
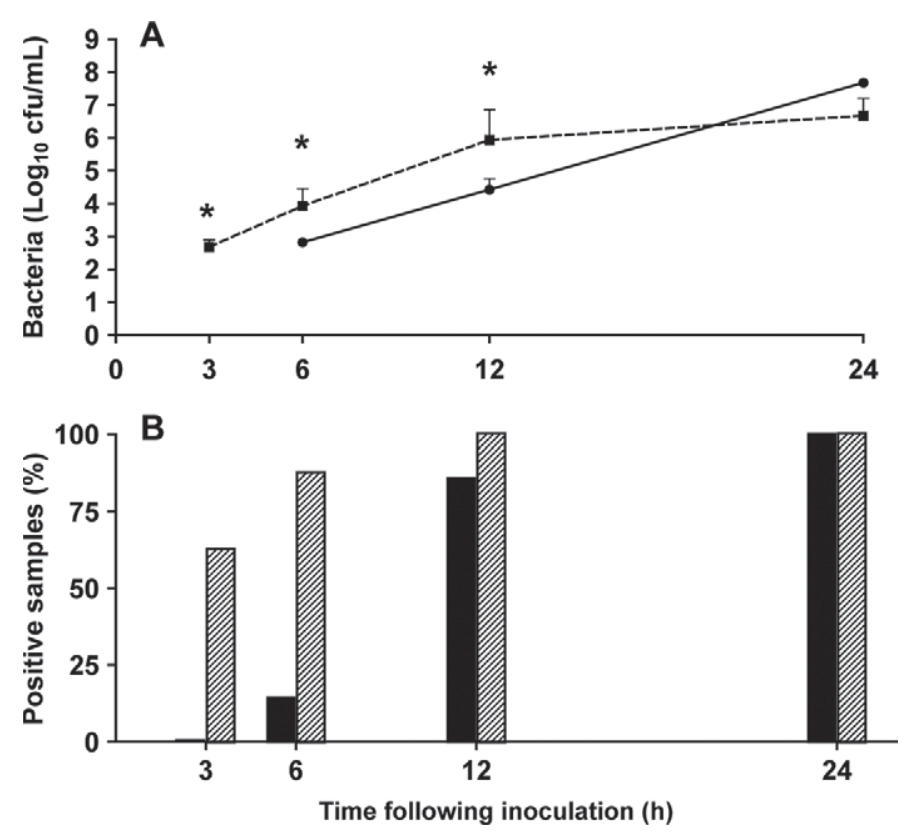

Figure 1. (A) In vitro growth curves of Streptococcus uberis strain FSL Z1-048 (solid line) and FSL Z1-124 (dashed line) in milk from individual cows. Mean bacterial concentrations and SEM are shown for culture positive samples. Asterisks $(*)$ indicate significant differences between strains. (B) Proportion of milk samples from individual cows inoculated with Strep. uberis strain FSL Z1-048 (solid bars; $\mathrm{n}=$ 7) or FSL Z1-124 (hashed bars; $\mathrm{n}=8$ ) in which bacteria were detected (detection limit $=333 \mathrm{cfu} / \mathrm{mL})$. 
Table 3. Time (hours postinfusion) of first detection (bacteria; clinical signs other than fever) or first detected increase (temperature, SCC, cytokine levels) of several parameters in 6 cows challenged in 1 mammary quarter with Streptococcus uberis strain FSL Z1-048; apart from body temperature, all parameters were observed or measured at quarter level

\begin{tabular}{|c|c|c|c|c|c|c|}
\hline \multirow[b]{2}{*}{ Item } & \multicolumn{6}{|c|}{ Cow identification } \\
\hline & 1 & 2 & 3 & 4 & 5 & 6 \\
\hline Clinical signs & 30 & 30 & 36 & 36 & 48 & 36 \\
\hline Temperature & 30 & 24 & 24 & 30 & 72 & 36 \\
\hline SCC & 30 & 30 & 30 & 30 & 42 & 36 \\
\hline Bacteria & 12 & 18 & 12 & 12 & 18 & 18 \\
\hline IL-1及 & 30 & 36 & 30 & 30 & 42 & 36 \\
\hline IL-6 & 30 & 36 & 30 & 30 & 42 & 30 \\
\hline IL-8 & 30 & 30 & 30 & 30 & 42 & 36 \\
\hline IL-10 & 36 & 36 & 30 & 36 & 48 & 42 \\
\hline IL-12p40 & 36 & 36 & 36 & 36 & 48 & 42 \\
\hline TNF- $\alpha^{1}$ & 36 & 36 & 42 & 36 & 48 & 36 \\
\hline IL-17A & 144 & $\mathrm{ND}^{2}$ & 72 & 57 & ND & 72 \\
\hline
\end{tabular}

induce a clinical response; however, no difference in response was observed between animals challenged with either the low or the high dose of this strain. Viable Strep. uberis was isolated from milk from all mammary quarters $(\mathrm{n}=6)$ infused with FSL Z1-048 (Figure 3A). Bacteria were first detected at $12 \mathrm{~h} \mathrm{PI}$, and all quarters were positive at $18 \mathrm{~h}$ PI (Figure 3B). By $81 \mathrm{~h} \mathrm{PI}$, the number of culture positive quarters started to fluctuate. Five of 6 animals had cleared the infection spontaneously by the end of the study, at $312 \mathrm{~h}$ postchallenge (Figure 3B), as confirmed by culture of milk samples collected on a daily basis for $10 \mathrm{~d}$ after the end of the study. The maximum average concentration of Strep. uberis in positive quarters was observed at $36 \mathrm{~h} \mathrm{PI} \mathrm{(7.67}$ $\pm 0.35 \log _{10} \mathrm{cfu} / \mathrm{mL}$; Figure 3A). By $96 \mathrm{~h}$ PI, bacterial concentration had decreased to $3.49 \pm 0.54 \log _{10} \mathrm{cfu} /$ $\mathrm{mL}$, and it remained at a similar level in culture positive quarters for the rest of the follow-up period (Figure $3 \mathrm{~A})$. Streptococcus uberis was recovered in milk from 4 quarters challenged with strain FSL Z1-124 between 12 and $48 \mathrm{~h} \mathrm{PI}$, of which 3 had been challenged with the low dose and 1 with the high dose. No more than 2 quarters were positive at any given time (Figure 3B). Average concentration in positive quarters reached its maximum at $24 \mathrm{~h}$ postchallenge $\left(2.91 \pm 0.55 \log _{10} \mathrm{cfu} /\right.$ $\mathrm{mL}$; Figure 3A) and all quarters were negative for FSL Z1-124 by $57 \mathrm{~h}$ PI.

From each quarter challenged with strain FSL Z1048, 3 isolates were used for PCR and PFGE (i.e., 1 isolate representing the first isolation, peak concentration, and last isolation from each quarter, respectively, for a total of 18 isolates). All isolates were confirmed to be Strep. uberis by PCR; PFGE patterns of all isolates matched that of the challenge strain (Figure 4). Only a limited number of isolates from quarters chal- lenged with FSL Z1-124 were available for analysis, that is, 1 isolate from 1 quarter and 3 isolates obtained at 3 different time points $(12,18$, and $24 \mathrm{~h} \mathrm{PI}$ ) from a different quarter. Polymerase chain reaction using species-specific primers yielded a band of $470 \mathrm{bp}$ rather than the expected $330 \mathrm{bp}$. Sequence analysis of the PCR amplicon revealed a $160 \mathrm{bp}$ insertion in the 16S-23S rRNA intergenic spacer region. The insertion fragment showed 99\% sequence homology with the 16S-23S intergenic spacer region of Streptococcus porcinus (ATCC35647). Otherwise, the 16S-23S rRNA intergenic spacer amplicon showed $100 \%$ sequence homogeneity with that of Strep. uberis reference strains O140J, ATCC70047, and ATCC19436. Sequencing of a $740 \mathrm{bp}$ fragment of a second housekeeping gene, rpoB (Drancourt et al., 2004), confirmed the species identity of FSL Z1-124 as Strep. uberis. The PFGE patterns of isolates from quarters challenged with FSL Z1-124 were indistinguishable from the PFGE pattern of the challenge strain (Figure 4).

\section{SCC and Flow Cytometry}

All quarters challenged with strain FSL Z1-048 showed an increase in SCC. In individual quarters, elevation of SCC was first observed 30 to $42 \mathrm{~h}$ PI (Table 3). Mean SCC reached its peak $\left(7.40 \pm 0.07 \log _{10}\right.$ cells/ $\mathrm{mL}$ ) at $42 \mathrm{~h}$ PI and remained elevated throughout the study (Figure 5). Phosphate-buffered saline-infused control quarters from animals challenged with FSL Z1-048 showed a significant increase in SCC compared with prechallenge levels at several time points postchallenge (e.g., during peak milk yield depression and toward the end of the study; Figure 5). The elevation in SCC was observed in animals challenged with strain FSL Z1-124 

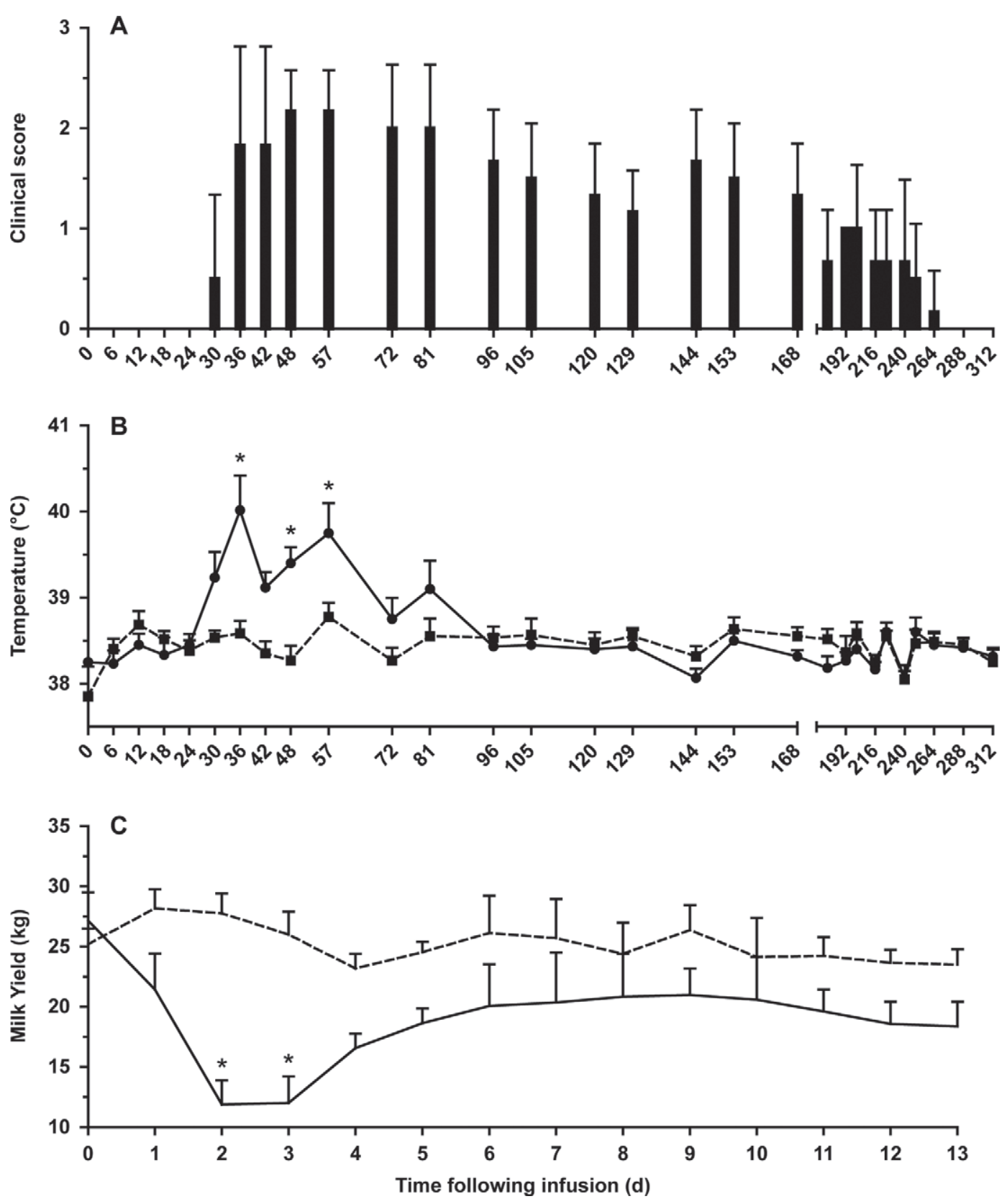

Figure 2. (A) Clinical score in response to intramammary challenge with Streptococcus uberis strain FSL Z1-048. Mean and SEM for 6 cows. $0=$ no clinical signs; $1=$ abnormalities in milk (e.g., clots or discoloration); $2=$ abnormalities in udder (e.g., swelling or pain); $3=$ systemic signs (e.g., fever). None of the cows $(\mathrm{n}=6$ ) challenged with strain FSL Z1-124 showed clinical signs. (B) Rectal temperature in response to intramammary challenge with FSL Z1-048 (solid line) or FSL Z1-124 (dashed line). Mean and SEM are shown. (C) Daily milk yield in response to intramammary challenge with Strep. uberis strain FSL Z1-048 (solid line) or FSL Z1-124 (dashed line). Daily milk yield was calculated as the sum of morning and afternoon milkings. Mean and SEM are shown for 6 cows per strain. Values marked by an asterisk $(*)$ are significantly different from those at $t=0(P<0.05)$.

in quarters infused with bacteria (Figure 5), but not control quarters infused with PBS (data not shown).

A large influx of PMNL in the early stage of the infection, confirmed by differential cell counts of cytocentrifuge preparations, affected the ability to quantify T-cell populations by flow cytometry, resulting in incomplete data on T-cell subsets for some time points (e.g., 96 h PI). In milk from quarters infused with strain FSL Z1-048, the mean concentration of $\mathrm{CD}^{+}$cells was significantly elevated from $96 \mathrm{~h}$ PI onwards, reaching its highest level at $312 \mathrm{~h}$ PI $\left(8.18 \times 10^{5} \pm 1.6 \times 10^{5}\right.$ cells/ $\mathrm{mL}$; Figure $6 \mathrm{~A}$ ). The concentration of $\mathrm{CD}^{+}$and $\mathrm{CD} 8^{+}$ 

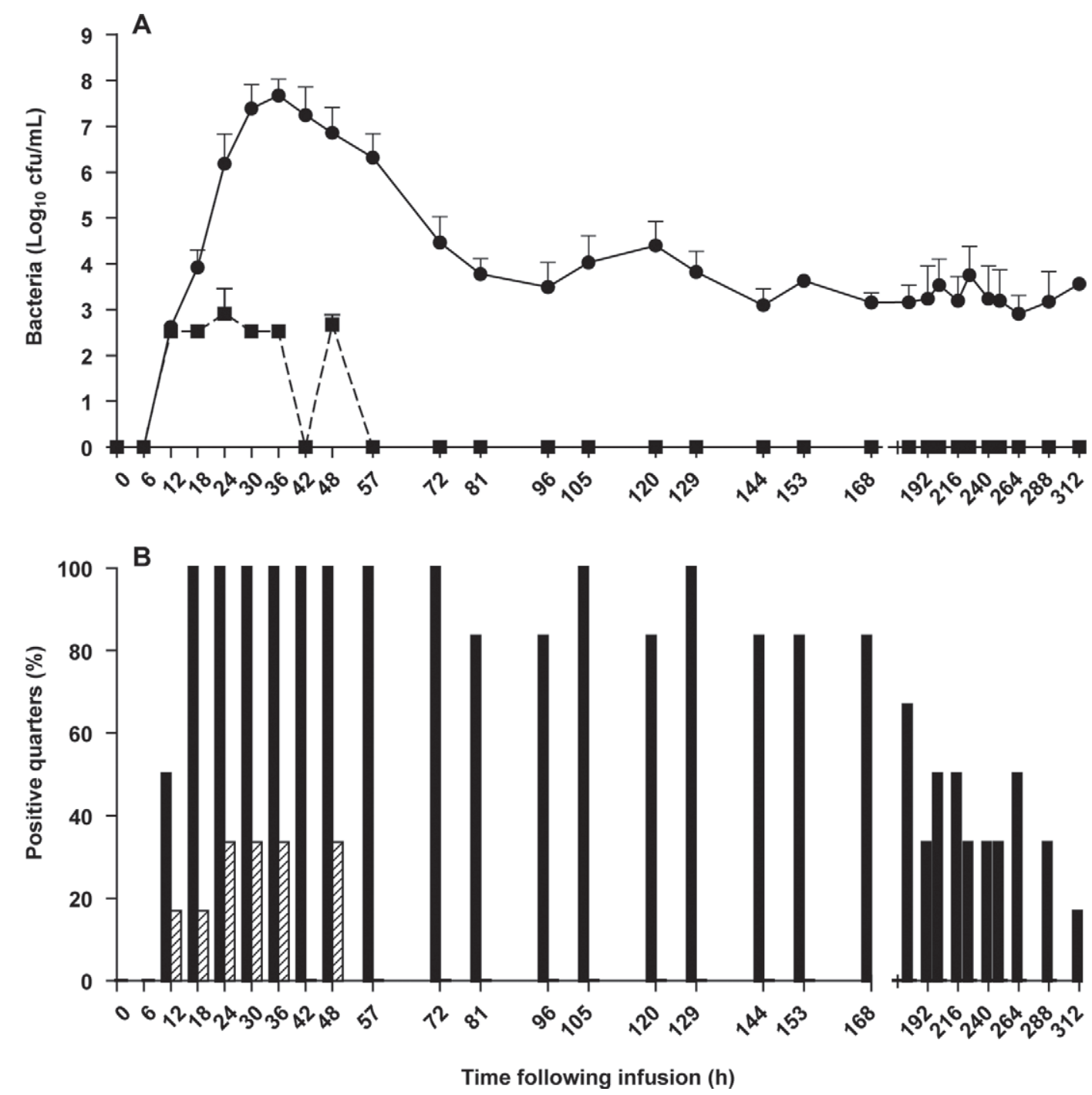

Figure 3. (A) Bacteria counts in milk of quarters excreting Streptococcus uberis strain FSL Z1-048 (solid line) or FSL Z1-124 (dashed line). Mean and SEM are shown. (B) Proportion of quarters challenged with Strep. uberis strain FSL Z1-048 (solid bars) or FSL Z1-124 (hashed bars) from which Strep. uberis was recovered. Six quarters (1 per cow) were challenged per strain.

lymphocyte subsets also increased from $96 \mathrm{~h}$ PI, with higher concentrations of $\mathrm{CD} 4^{+}$lymphocytes compared with $\mathrm{CD} 8^{+}$lymphocytes present in initial stages of infection. The concentration of $\mathrm{CD} 4^{+}$cells stabilized after the initial increase, whereas the concentration of $\mathrm{CD} 8^{+}$ cells increased from 144 to $312 \mathrm{~h} \mathrm{PI} \mathrm{(Figure} \mathrm{6B} \mathrm{and} \mathrm{C).}$ As a result, the mean ratio between the 2 populations changed over time, from 0.69 at time 0 to a peak at 2.8 at 96 h PI (Figure 7). The ratio remained inverted compared with the PBS-infused control quarters until $240 \mathrm{~h}$ PI $(P<0.05)$ and returned to normal at $312 \mathrm{~h}$ PI. The concentration of $\gamma / \delta$ cells increased from $144 \mathrm{~h}$ $\mathrm{PI}$, from $194 \pm 171$ cells $/ \mathrm{mL}$ at time 0 to $4.6 \times 10^{4} \pm$ $2.7 \times 10^{4}$ cells $/ \mathrm{mL}$ at $144 \mathrm{~h} \mathrm{PI}$, and remained elevated compared with the control quarters until the end of the study $\left(4.4 \times 10^{4} \pm 3.1 \times 10^{4}\right.$ cells $/ \mathrm{mL}$ at $312 \mathrm{~h}$; Figure 6D). Concentrations of $\mathrm{CD}^{+}$cells and $\mathrm{CD} 4^{+}$, $\mathrm{CD} 8^{+}$, or $\gamma / \delta$ subsets did not change in milk from cows challenged with strain FSL Z1-124 (data not shown).

\section{Cytokine Response}

All quarters challenged with FSL Z1-048 showed an increase in concentration of IL- $1 \beta$, TNF- $\alpha$, IL- 8 , IL-6, IL-12p40, and IL10, and 4 of 6 quarters showed an increase in concentration of IL-17A (Table 3). Interleukin$1 \beta$ was first detected in challenged quarters at 30 to $42 \mathrm{~h}$ PI (Table 3), whereas no increase was found in control quarters infused with PBS. Mean IL-1 $\beta$ concentration reached its highest level $(327 \pm 102 \mathrm{pg} / \mathrm{mL})$ at 


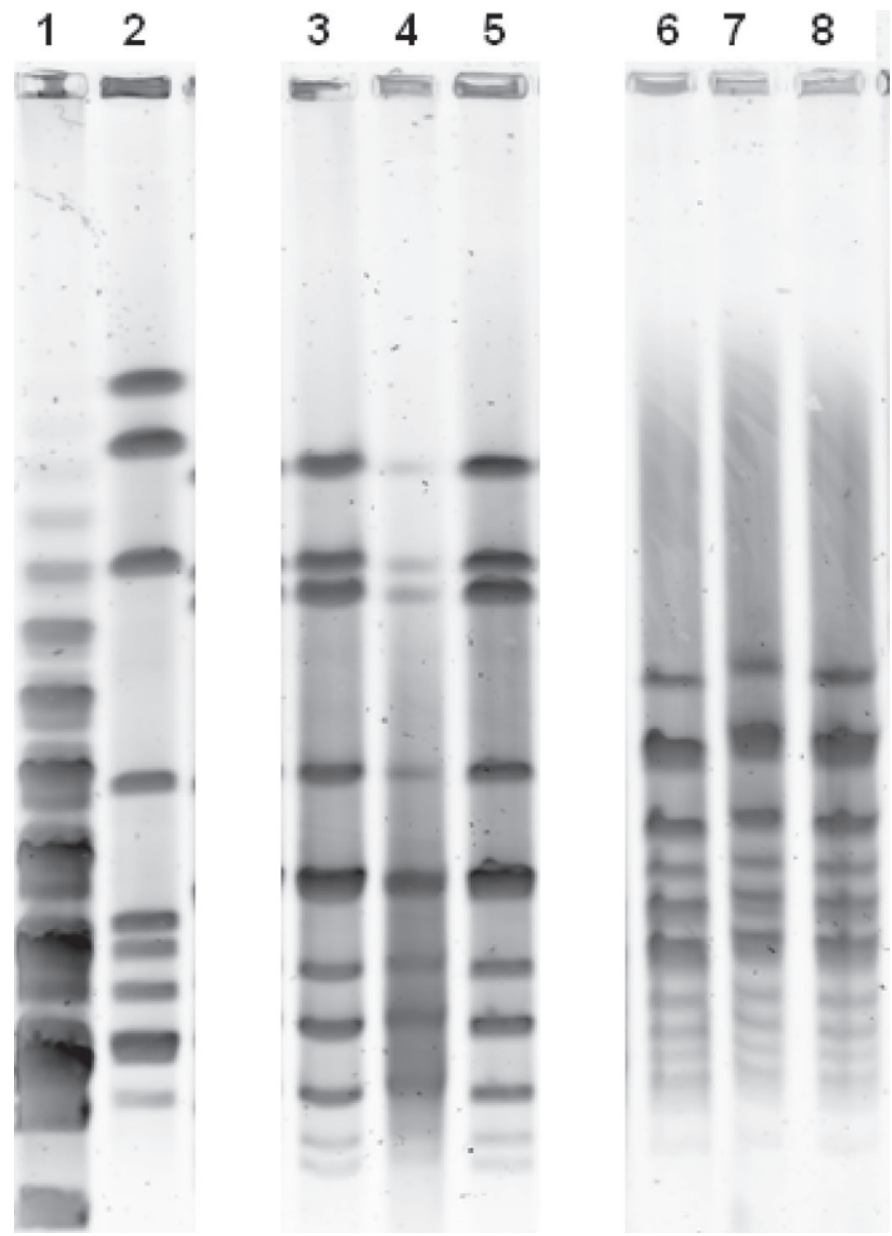

Figure 4. Examples of pulsed-field gel electrophoresis patterns of Streptococcus uberis isolates from quarters challenged with strain FSL Z1-048 (lanes 6 and 8) or FSL Z1-124 (lanes 3 and 5). The respective challenge strains were included for comparison (lane 4 and lane 7). Lanes 1 and 2 show a DNA ladder (concatamers of $\lambda$ DNA) and a marker strain (Streptococcus agalactiae STIR-CD-25), respectively.

48 h PI (Figure 8A). Tumor necrosis factor- $\alpha$ was first detected between 36 and $48 \mathrm{~h}$ PI and the highest mean concentration $(1,219 \pm 599 \mathrm{pg} / \mathrm{mL})$ was observed at 36 h PI (Figure 8B). Interleukin-8 was first detected at 30 to $42 \mathrm{~h}$ PI (Table 3 ), and the highest mean IL-8 concentration $(4.2 \pm 0.2 \log 10 \mathrm{pg} / \mathrm{mL})$ was reached at $48 \mathrm{~h} \mathrm{PI}$ (Figure 8C). Five of 6 control quarters in FSL Z1-048 challenged animals showed a moderate increase in IL-8 concentration (peak of mean concentration $1.72 \pm 0.36$ $\log _{10} \mathrm{pg} / \mathrm{mL}$ ), which coincided with peak concentrations in challenged quarters (Figure 8C). Interleukin-6 was first detected at 30 to $42 \mathrm{~h}$ PI (Table 3). The IL-6 curve was bimodal, with peaks at 48 and $72 \mathrm{~h}$ PI (11.3 \pm 2.8 and $11.2 \pm 2.9 \mathrm{ng} / \mathrm{mL}$, respectively; Figure $8 \mathrm{D}$ ). Increased IL-12p40 concentration was first detected at 30 to 48 h PI (Table 3). Mean IL-12p40 concentration peaked at $48 \mathrm{~h}$ PI $[124 \pm 35$ biological units (bU)/
$\mathrm{mL}$; Figure 8E]. Increased IL-10 concentration was first detected at 30 to $42 \mathrm{~h}$ PI (Table 3), and the peak in mean concentration $(35.6 \pm 8.2 \mathrm{bU} / \mathrm{mL})$ occurred at $48 \mathrm{~h} \mathrm{PI}$ (Figure 8F). Interferon- $\gamma$ was detected at 1 or 2 isolated time points in milk from some challenged quarters, whereas in other quarters, the concentration was elevated for up to 10 consecutive time points. This variability was also observed in PBS-infused control quarters (Figure 8G). The first increase in IL-17A concentration was detected 57 to $144 \mathrm{~h}$ PI (Table 3), and mean IL-17A concentration reached its peak $(463 \pm$ $345 \mathrm{pg} / \mathrm{mL}$ ) at $81 \mathrm{~h}$ postchallenge (Figure $8 \mathrm{H}$ ). The elevation in concentration of IL-17A coincided with the decrease in concentration of Strep. uberis bacteria in milk from infected quarters (Figure 9). All 4 animals that showed an increase in levels of milk IL-17A cleared the infection before the end of the study, whereas 1 of 2 animals without a detectable IL17-A response did not clear the infection spontaneously.

For quarters challenged with strain FSL Z1-124, cytokines were measured in milk samples collected at all time points for 1 animal, and at time points up to 81 $\mathrm{h}$ PI for the remaining 5 animals. No increase in concentration of IL-1 $\beta$, TNF- $\alpha$, IL-6, IL-10, IL-12p40, or IL-17A was observed in challenged or control quarters of cows challenged with strain FSL Z1-124. Low levels of IL-8 were detected in 3 of 6 quarters challenged with strain FSL Z1-124 (data not shown). Elevations in IL-8 concentration were observed between 12 and $48 \mathrm{~h}$ PI, ranging from 32.2 to $72.6 \mathrm{pg} / \mathrm{mL}$, and only occurred in quarters in which the challenge strain was recovered.

\section{DISCUSSION}

We observed clear differences in the ability of a putatively host-adapted and nonadapted strain of Strep. uberis (FSL Z1-048 and FSL Z1-124, respectively) to cause mastitis in lactating cows, with clinical signs, PMNL and lymphocyte influx, and multiple cytokine responses developing in all of the quarters challenged with the putatively host-adapted strain and none of the quarters challenged with the nonadapted strain, even when the dose of the nonadapted strain was increased 100-fold. By associating low ability to cause IMI with the nonadapted strain and high ability to cause IMI with the putatively host-adapted strain, which were identified as such using epidemiological and molecular data, our results support the hypothesis that strains of Strep. uberis that predominate within herds are more adapted to colonizing the mammary gland than those which are only sporadically identified as a cause of mastitis. Thus, differences in incidence of strain-specific IMI are not simply due to different levels of exposure. The observation in the current study that IMI caused by 


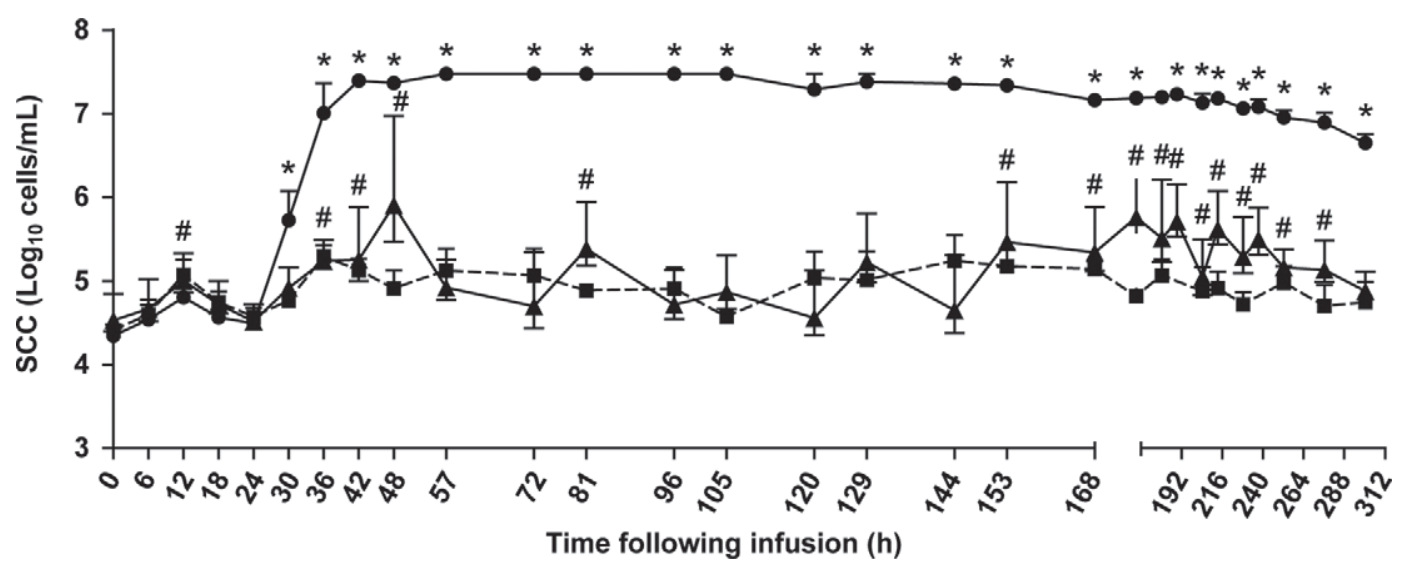

Figure 5. Somatic cell count in response to challenge with Streptococcus uberis strain FSL Z1-048 (solid lines) or FSL Z1-124 (dashed line). Main and SEM are shown for challenge quarters $(\bullet)$ and PBS-infused control quarters $(\boldsymbol{\Delta})$ of animals challenged with strain FSL Z1-048. The PBS-infused control quarters of animals challenged with FSL Z1-124 did not show elevation of SCC compared with prechallenge levels (data not shown). Significant differences $(P<0.05)$ between pre- and postchallenge levels are shown for challenge and PBS-infused control quarters of animals challenged with FSL Z1-048 (* and \#, respectively).
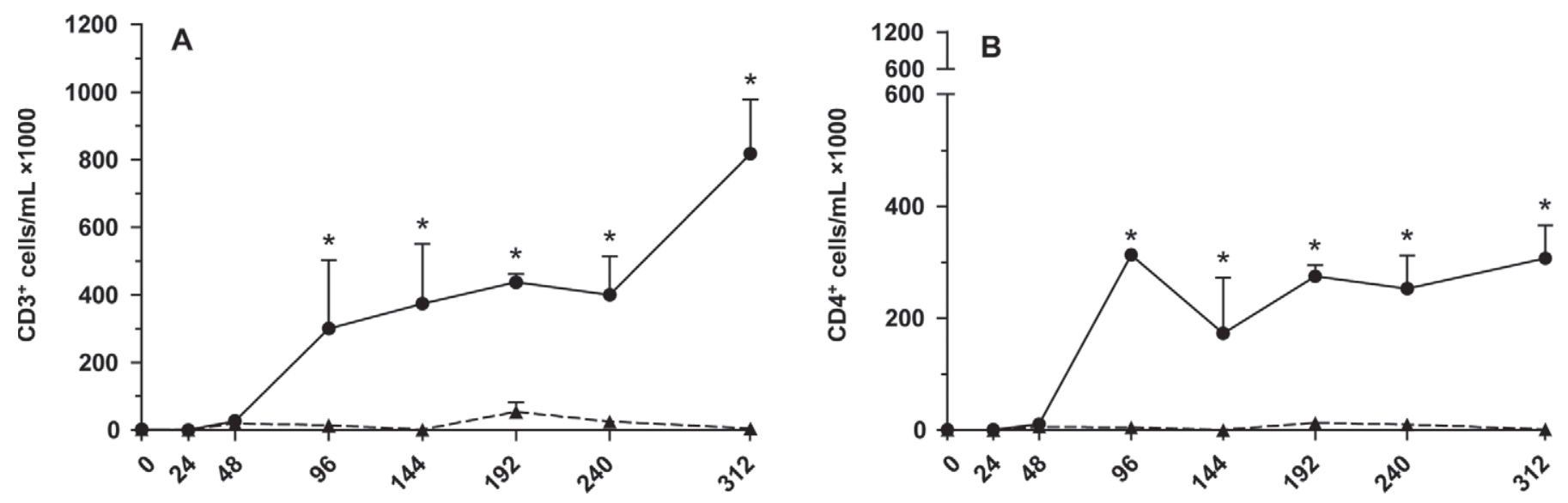

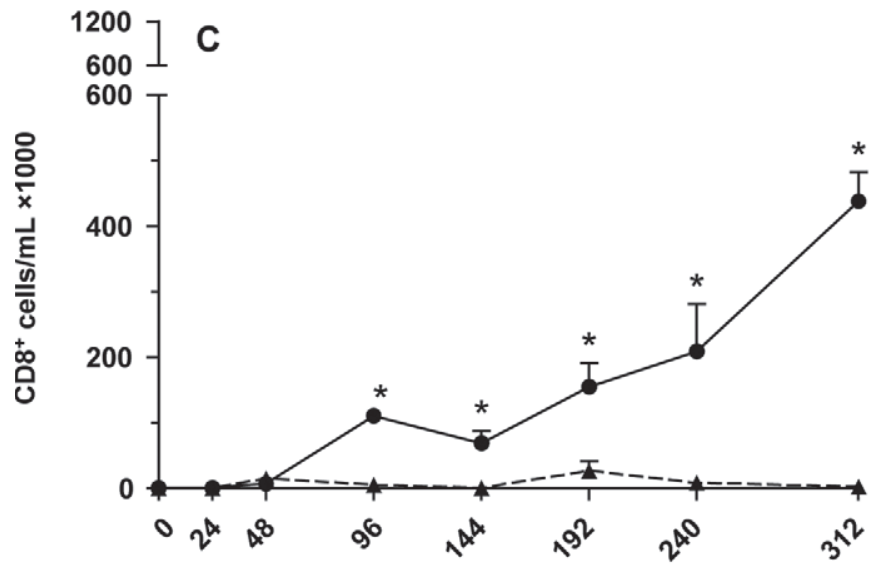

Time following infusion (h)

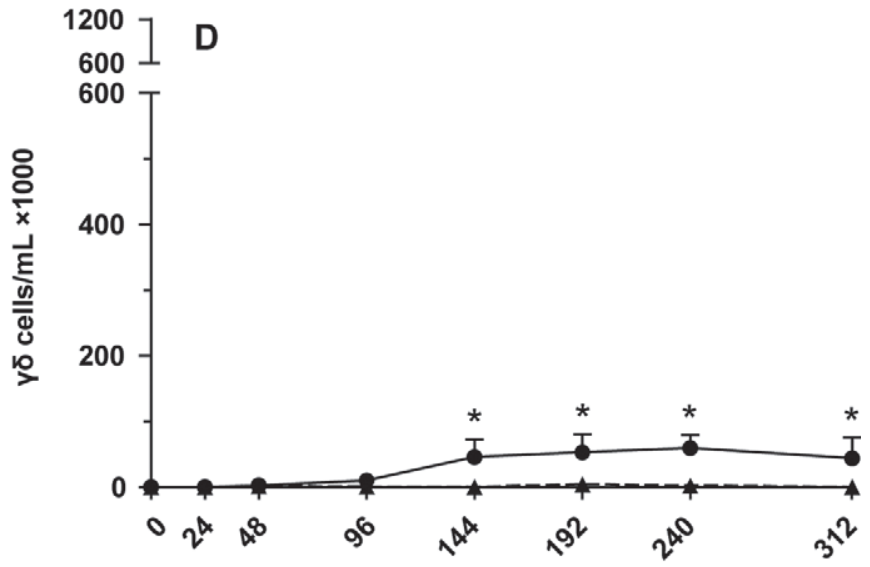

Time following infusion (h)

Figure 6. Concentration in milk of $\mathrm{CD}^{+}(\mathrm{A}), \mathrm{CD}^{+}(\mathrm{B}), \mathrm{CD} 8^{+} \mathrm{l}(\mathrm{C})$, and $\gamma / \delta(\mathrm{D})$ lymphocytes in milk. Mean and SEM are shown for quarters infused with strain FSL Z1-048 (solid line) and PBS-infused control quarters (dashed line) of the same animals. Asterisks $(*)$ indicate significant differences between challenged quarters and PBS-infused control quarters. Models for $\gamma / \delta$ lymphocytes did not converge. 


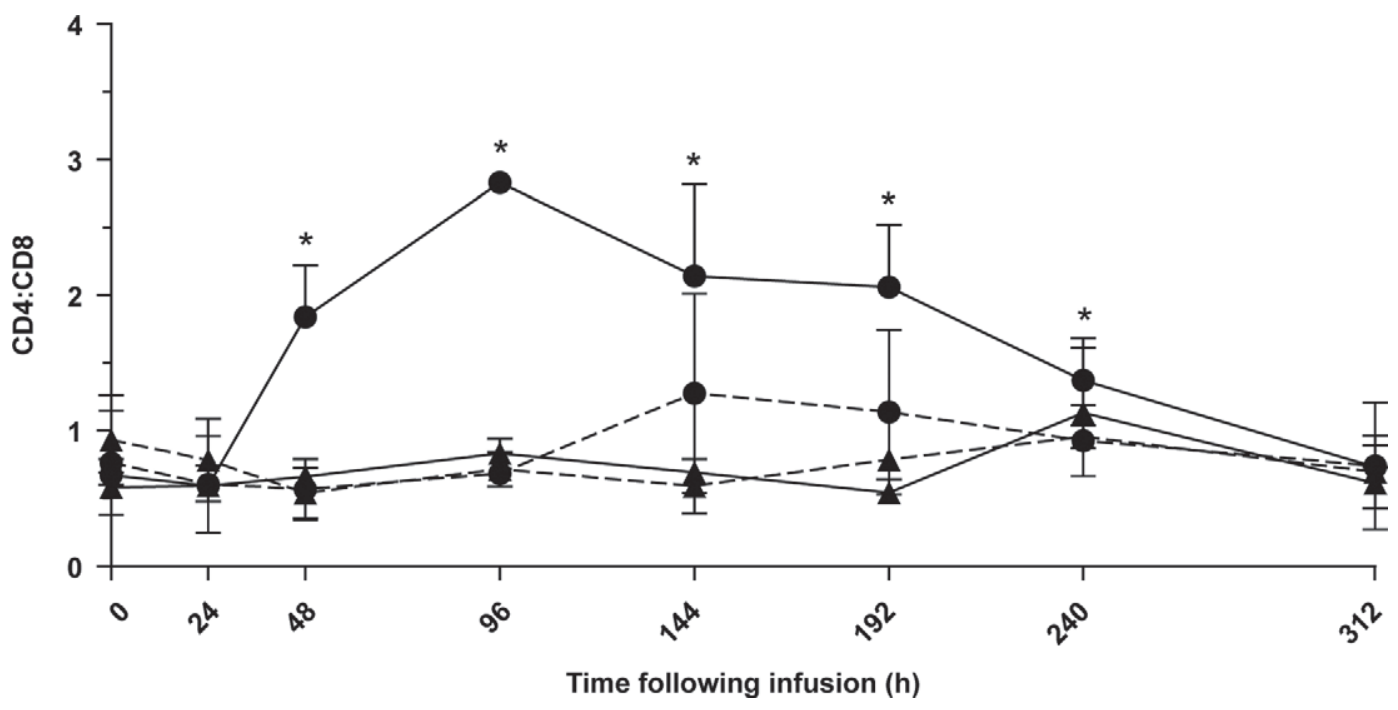

Figure 7. The $\mathrm{CD} 4^{+}$-to-CD8 ${ }^{+}$ratio in milk from cows challenged with Streptococcus uberis strain FSL Z1-048 (solid lines) or FSL Z1-124 (dashed lines). Mean and (where possible) SEM are shown for challenged quarters $(\bullet)$ and PBS-infused control quarters $(\boldsymbol{\Lambda})$. Data were available for 5 or 6 quarters per strain at times 0 and 24, for 1 or 2 quarters per strain at time 96 , and for 3 or 5 quarters per strain for other time points. Asterisks $\left(^{*}\right)$ indicate significant differences between challenge quarters and PBS-infused control quarters for animals challenged with FSL Z1-048.

the putatively host-adapted strain resulted in clinical mastitis and often cured spontaneously was unexpected, as this strain had previously been associated with persistent infection and mostly subclinical mastitischaracteristics that have been considered indicative of host-adaptation (Zadoks et al., 2003; Zadoks, 2007). Differences between natural and experimental IMI with regards to challenge dose and method of exposure (e.g., deposition of bacteria in the teat cistern via a cannula), may have contributed to the observed differences in host response.

The ability to grow in milk is a potential virulence factor of Strep. uberis because rapid growth enables bacteria to replicate within the mammary gland at a rate exceeding that by which they are cleared via milking (Leigh, 1999; Kliem and Hillerton, 2002; Rambeaud et al., 2004). Growth rate is unlikely to explain the observed difference in pathogenicity in the current study, however, because the nonadapted strain grew faster in the milk of challenge animals than the putatively hostadapted strain. The strains may differ in their capacity to attach to or invade mammary epithelium, which has been suggested to be important for mammary colonization by Strep. uberis (Matthews et al., 1994). Alternatively or additionally, the strains may differ in their ability to resist killing by PMNL or mammary macrophages, although the contribution of those cell types to clearance of Strep. uberis IMI is debated (Leigh, 1999). No significant cellular response was observed following challenge with FSL Z1-124 and, with the exception of low levels of IL- 8 detected in 3 of the 4 challenged quarters from which FSL Z1-124 was recovered, no cytokine response was detected. Despite its ability to grow in milk, this strain largely disappeared without a trace, implying that its clearance is due to resident cells, molecules, or mechanisms, rather than to influx of cells into the mammary gland. By contrast, challenge with the putatively host-adapted strain, FSL Z1-048, resulted in a significant cellular and cytokine response in the mammary gland.

The onset of clinical, bacteriological, cellular, and cytokine events within the mammary gland relative to challenge differed between animals, but the sequence and timing of these events within animals was relatively constant. To our knowledge, this is the first description of this orchestration of events at the cow level because cytokine data from other Strep. uberis challenge models are presented across rather than within cows (Rambeaud et al., 2003; Bannerman et al., 2004a). The increase in colony-forming units count was detected at 12 to 18 h PI and preceded detectable increases in SCC by 12 to $24 \mathrm{~h}$. The initial increase in SCC was largely due to an influx of PMNL in the mammary gland and SCC reached its highest level at $36 \mathrm{~h}$ PI, which coincided with peak colony-forming unit level. After that time point, SCC stayed high, whereas the concentration of Strep. uberis in milk from infected quarters decreased approximately $10^{4}$-fold. This suggests that neutrophils play a role in the initial decrease in the colony-forming unit count of Strep. uberis, in agreement with results from previous challenge studies (Hill, 1988; Pedersen et al., 2003). The initial increase in SCC coincided with 

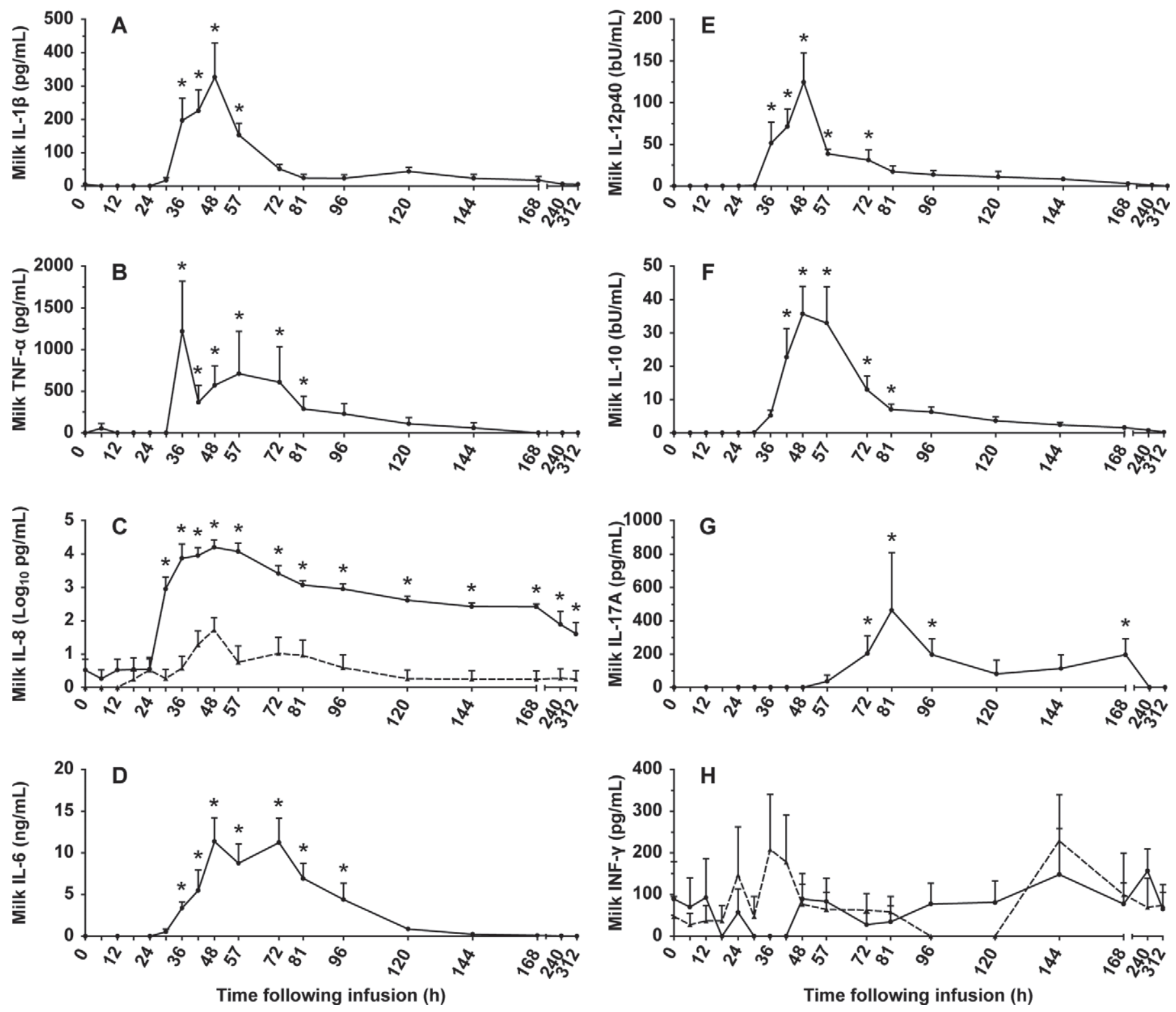

Figure 8. Cytokine concentration in milk from cows challenged with Streptococcus uberis strain FSL Z1-048. Mean and SEM are shown for challenge quarters (solid line) and, where postchallenge levels were above the detection limit, for PBS-infused control quarters (dashed line). (A) Concentration of IL-1 $\beta$ (detection limit $31.25 \mathrm{pg} / \mathrm{mL}$ ). (B) Concentration of tumor necrosis factor- $\alpha$ (TNF- $\alpha$ detection limit $125 \mathrm{pg} / \mathrm{mL}$ ). (C) Concentration of IL-8 (detection limit $0.031 \mathrm{ng} / \mathrm{mL}$ ). (D) Concentration of IL-6 (detection limit $78.25 \mathrm{pg} / \mathrm{mL}$ ). (E) Concentration of IL-12p40 (detection limit 0.366 biological units $/ \mathrm{mL}$ ). (F) Concentration of IL-10 (detection limit $0.825 \mathrm{bU}$ ). (G) Concentration of IL-17A (detection limit $188 \mathrm{pg} / \mathrm{mL})$. (H) Concentration of IFN- $\gamma$ (detection limit $156.125 \mathrm{pg} / \mathrm{mL}$ ). Asterisks $\left(^{*}\right)$ indicate significant elevation compared with prechallenge levels $(P<0.05)$

the first detectable increase in IL-8 in all animals. In a challenge model using Strep. uberis strain O140J, SCC increases also coincided with increase in IL-8, and both were detected at $30 \mathrm{~h}$ postchallenge (Bannerman et al., 2004a). These observations are consistent with the role of IL-8 in neutrophil chemotaxis (Harada et al., 1994). In a third challenge study, SCC increase preceded the first detected increase in IL- 8 by approximately $6 \mathrm{~h}$ (Rambeaud et al., 2003). In all 3 challenge studies with
Strep. uberis, the increase in IL-8 levels was sustained for days, which was not the case in challenge studies with different mastitis pathogens (i.e., Escherichia coli, Klebsiella pneumoniae, Serratia marcescens, or Staphylococcus aureus; Bannerman et al., 2004a,b,c), where IL-8 levels did not increase measurably (Staph. aureus) or only for the first 18 to $72 \mathrm{~h}$ postchallenge (gramnegative pathogens). The early inflammatory response was also characterized by increased levels of the proin- 

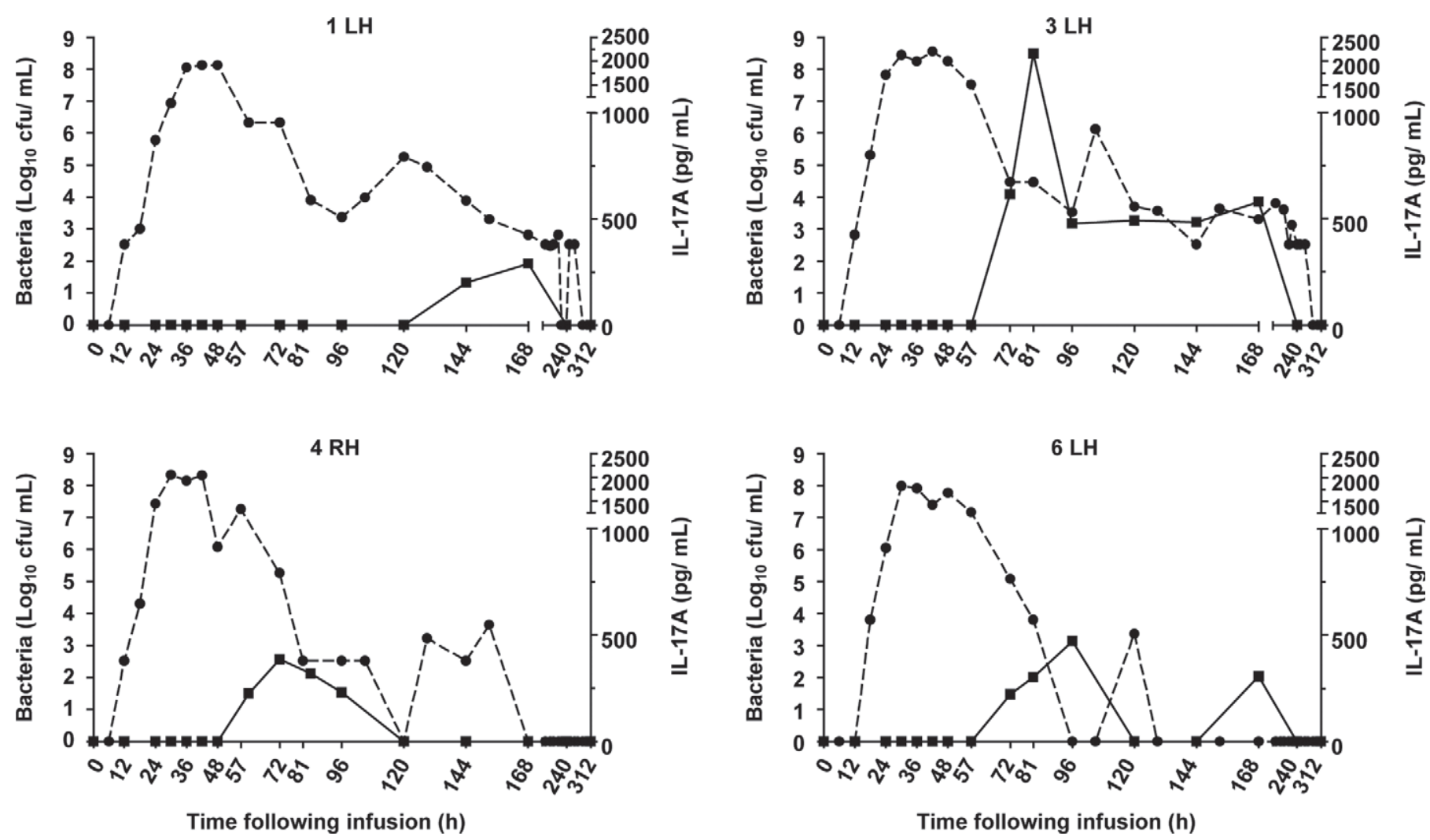

Figure 9. Concentration of Streptococcus uberis bacteria (dashed line) and IL-17A (solid line) in milk from mammary quarters challenged with strain FSL Z1-048. Quarters with detectable IL-17A are shown. Elevation of IL-17A coincided with decreased concentration of bacteria after the initial peak. All the quarters with detectable IL-17A cleared the infection by the end of the study (312 h postinfusion). Cow identification numbers match those in Table $3 . \mathrm{LH}=$ left hind quarter; $\mathrm{RH}=$ right hind quarter.

flammatory cytokines IL-1 $\beta$ and IL-6, which were first detected at 30 to $42 \mathrm{~h}$ PI. Levels of IL-13, which is both proinflammatory and pyrogenic, showed a single peak and remained significantly elevated until $57 \mathrm{~h}$ PI, which is consistent with the observed increase in body temperature in our study, but earlier and shorter than described for other Strep. uberis strains (Rambeaud et al., 2003; Bannerman et al., 2004a). Thus, the immune response to mammary pathogens differs between bacterial species as well as bacterial strains. The IL-6 peak appeared to be bimodal, with peaks at 48 and $72 \mathrm{~h}$ PI, and levels remained significantly elevated until $96 \mathrm{~h}$ PI. This may reflect the role of IL-6, which has both proinflammatory and anti-inflammatory activity and plays a role in the transition from innate to adaptive immunity, for example by modulating $\mathrm{T}$ cell polarization or promoting $\mathrm{T}$ cell trafficking into tissues (Jones, 2005). After intramammary challenge with Strep. uberis, IL-6 mRNA expression is upregulated in blood PMNL (Moyes et al., 2010), and its detection in milk may be due to migration of PMNL to the mammary gland. Alternatively, upregulation of IL-6 mRNA expression may occur locally, as both milk cells and mammary epithelial cells can express the cytokine (Taylor et al., 1997; Zhu et al., 2012). The IL-6 response to intramammary challenge with Strep. uberis has not been described before. In field studies, the IL-6 response was similar between cows with clinical mastitis due to streptococci, staphylococci, or E. coli (Taylor et al., 1997). In humans and mice, IL-6 attracts lymphocytes (Weissenbach et al., 2004; McLoughlin et al., 2005); it is unknown whether IL-6 has a similar function in cattle, but IL-6 levels increased before a lymphocyte influx was observed, making this a possibility. An increase in levels of TNF- $\alpha$, IL-10, and IL-12p40 was generally first detected $6 \mathrm{~h}$ after the increase in IL-8 (Table 3), and levels remained elevated for up to 72 to $81 \mathrm{~h}$ PI. The observed increase in IL-12p40 levels may indicate the presence of IL-12 or IL-23, because they share the p40 subunit (Oppmann et al., 2000) After challenge with Strep. uberis strain O140J, IL-10 and IL-12 levels increased at the same time as IL-8 levels, and remained high for up to $168 \mathrm{~h}$ (Bannerman et al., 2004a). A major difference between our study and the study by Bannerman et al. (2004a) is that colony-forming unit counts continued to increase in their study, whereas, 
in our study, colony-forming unit counts stabilized around 72 to $81 \mathrm{~h}$ PI and spontaneous resolution of infection was first observed around that time (Figure $3)$. At this stage in the process, the first detectable rise in IL-17A occurred and so did the influx of $\mathrm{CD}^{+}$and $\mathrm{CD} 8^{+} \mathrm{T}$ lymphocytes, although the exact time of onset of lymphocyte influx was not measured (Figure 6,8). Interleukin-17A is produced primarily by $\mathrm{CD} 4^{+} \mathrm{TH} 17$ cells; in vitro, the differentiation of naive T-cells in CD $4^{+}$Th17 cells is supported by IL- 6 and TGF- $\beta 1$. This effect is enhanced by the presence of IL- $1 \beta$ and TNF- $\alpha$, and subsequent maintenance of Th17 cells is promoted by IL-23 (Veldhoen et al., 2006; Stritesky et al. 2008). The same cytokines may play a role in the response of cows to intramammary challenge with Strep. uberis, given that elevation of IL-1 $\beta$ and IL-6 levels was followed by elevation of IL-12p40 or IL-23 and TNF- $\alpha$ levels and, finally, elevation of the IL-17A level. Indeed, at this stage in the inflammatory process, the number of $\mathrm{CD}^{+}$cells increased more rapidly than the $\mathrm{CD} 8^{+}$ cell population, resulting in an inversion of the CD4to-CD8 ratio (Figure 6). Similar inversion of the CD4to-CD8 ratio occurs in cows with naturally occurring mastitis due to Streptococcus spp. (Taylor et al., 1997; Soltys and Quinn, 1999). The CD $4^{+}$level remained high but, due to continued increases in $\mathrm{CD} 8^{+}$level, the ratio normalized after $240 \mathrm{~h}$ PI. Spontaneous resolution of infection occurred in 5 animals. Resolution of infection was preceded by measurable levels of IL-17A in 4 of 6 animals, and was temporally associated with increased lymphocyte levels. Although the number of observations in the current study is too limited to draw solid conclusions, it raises interesting questions with regard to the role of IL-17A or lymphocytes in Strep. uberis IMI. Interleukin-17 may be important for control of extracellular bacterial infections (Curtis and Way, 2009); in mice, IL-17A mediates acquired immunity to streptococcal colonization and infection, possibly through enhanced pneumococcal killing by PMNL ( $\mathrm{Lu}$ et al., 2008). In vitro, IL-17 upregulates genes that encode antimicrobial proteins in bovine mammary epithelial cells, providing an alternative mechanism for bacterial killing (Bougarn et al., 2011). Our observations after experimental challenge are compatible with a role of IL-17A in the control of Strep. uberis infection, and the temporal association of increased levels of $\mathrm{CD} 4^{+} \mathrm{T}$ cells and IL17-A within the milk suggests that CD4 ${ }^{+}$ $\mathrm{T}$ cells may be the principal cellular source of IL17-A. Bacterial killing may also be affected by lymphocytes. A recent study suggested that Strep. uberis-specific $\mathrm{CD} 8^{+}$cells are present in most cows, regardless of prior IMI with Strep. uberis, and that they have a direct killing activity against Strep. uberis in vitro (Denis et al., 2011). The observed sequence of events in our study is compatible with a role of lymphocytes in clearance of infection.

\section{CONCLUSIONS}

In conclusion, our study demonstrates that putatively host-adapted strain FSL Z1-048 and nonadapted strain FSL Z1-124, which caused IMI with different epidemiological patterns in a field study, reproducibly elicit distinct clinical and immune responses after experimental challenge of lactating dairy cows. Moreover, this study suggests that neutrophils, lymphocytes, and IL-17A may play important roles in reduction of bacterial load in the mammary gland and in clearance of Strep. uberis IMI, which merits further investigation.

\section{ACKNOWLEDGMENTS}

We thank Moredun Research Institute's Bioservices division, and in particular the stockmen, for their support during the challenge experiments. This study was financially supported by Pfizer Animal Health (Kalamazoo, MI).

\section{REFERENCES}

Bannerman, D. D., M. J. Paape, J. P. Goff, K. Kimura, J. D. Lippolis, and J. C. Hope. 2004a. Innate immune response to intramammary infection with Serratia marcescens and Streptococcus uberis. Vet. Res. 35:681-700.

Bannerman, D. D., M. J. Paape, W. R. Hare, and J. C. Hope. 2004b. Characterization of the bovine innate immune response to intramammary infection with Klebsiella pneumoniae. J. Dairy Sci. $87: 2420-2432$.

Bannerman, D. D., M. J. Paape, J. W. Lee, X. Zhao, J. C. Hope, and P. Rainard. 2004c. Escherichia coli and Staphylococcus aureus elicit differential innate immune responses following intramammary infection. Clin. Diagn. Lab. Immunol. 11:463-472.

Bougarn, S., P. Cunha, F. B. Gilbert, A. Harmache, G. Foucras, and P. Rainard. 2011. Staphylococcal-associated molecular patterns enhance expression of immune defense genes induced by IL-17 in mammary epithelial cells. Cytokine 56:749-759.

Bruno, D. R., P. V. Rossitto, R. G. Bruno, M. T. Blanchard, T. Sitt, B. V. Yeargan, W. L. Smith, J. S. Cullor, and J. L. Stott. 2010. Differential levels of mRNA transcripts encoding immunologic mediators in mammary gland secretions from dairy cows with subclinical environmental Streptococci infections. Vet. Immunol. Immunopathol. 138:15-24.

Curtis, M. M., and S. S. Way. 2009. Interleukin-17 in host defence against bacterial, mycobacterial and fungal pathogens. Immunol. 126:177-185.

Denis, M., N. A. Parlane, S. J. Lacy-Hulbert, E. L. Summers, B. M. Buddle, and D. N. Wedlock. 2006. Bactericidal activity of macrophages against Streptococcus uberis is different in mammary gland secretions of lactating and drying off cows. Vet. Immunol. Immunopathol. 114:111-120.

Denis, M., S. J. Lacy-Hulbert, B. M. Buddle, J. H. Williamson, and D. N. Wedlock. 2011. Streptococcus uberis-specific T cells are present in mammary gland secretions of cows and can be activated to kill Strep. uberis. Vet. Res. Commun. 35:145-156.

Dogan, B., and K. J. Boor. 2004. Short communication: Growth characteristics of Streptococcus uberis in UHT-treated milk. J. Dairy Sci. 87:813-815. 
Drancourt, M., V. Roux, P.-E. Fournier, and D. Raoult. 2004. rpoB gene sequence-based identification of aerobic gram-positive cocci of the genera Streptococcus, Enterococcus, Gemella, Abiotrophia, and Granulicatella. J. Clin. Microbiol. 42:497-504.

Entrican, G., A. Dand, and P. F. Nettleton. 1995. A double monoclonal antibody ELISA for detecting pestivirus antigen in the blood of viraemic cattle and sheep. Vet. Microbiol. 43:65-74.

Gillespie, B. E., B. M. Jayarao, J. W. Pankey, and S. P. Oliver. 1998. Subtyping of Streptococcus dysgalactiae and Streptococcus uberis isolated from bovine mammary secretions by DNA fingerprinting. Zentralbl. Veterinarmed. B. 45:585-593.

Harada, A., N. Sekido, T. Akahoshi, T. Wada, N. Mukaida, and K. Matsushima. 1994. Essential involvement of interleukin-8 (IL-8) in acute inflammation. J. Leukoc. Biol. 56:559-564.

Harp, J. A., T. E. Waters, J. P. Goff, D. D. Bannerman, and M. J. Paape. 2006. Expression of lymphocyte homing and adhesion molecules during intramammary infection of cows with Serratia marcescens or Streptococcus uberis: Correlation with bacterial colonization and clinical signs. Vet. Immunol. Immunopathol. 109:13-21.

Hill, A. W. 1988. Pathogenicity of two strains of Streptococcus uberis infused into lactating and non-lactating bovine mammary glands. Res. Vet. Sci. 45:400-404.

Jones, S. A. 2005. Directing transition from innate to acquired immunity: Defining a role for IL-6. J. Immunol. 175:3463-3468.

Kliem, K. E., and J. E. Hillerton. 2002. Possible labile inhibition of the growth of Streptococcus uberis in milk from cows free from mastitis. J. Dairy Res. 69:375-382.

Lang, P., T. Lefébure, W. Wang, R. N. Zadoks, Y. Schukken, and M. J. Stanhope. 2009. Gene content differences across strains of Streptococcus uberis identified using oligonucleotide microarray comparative genomic hybridization. Infect. Genet. Evol. 9:179-188.

Leigh, J. A. 1999. Streptococcus uberis: A permanent barrier to the control of bovine mastitis? Vet. J. 157:225-238.

Lu, Y.-J., J. Gross, D. Bogaert, A. Finn, L. Bagrade, Q. Zhang, J. K. Kolls, A. Srivastava, A. Lundgren, S. Forte, C. M. Thompson, K. F. Harney, P. W. Anderson, M. Lipsitch, and R. Malley. 2008. Interleukin-17A mediates acquired immunity to pneumococcal colonization. PLoS Pathog. 4:e1000159.

Matthews, K. R., R. A. Almeida, and S. P. Oliver. 1994. Bovine mammary epithelial cell invasion by Streptococcus uberis. Infect. Immun. 62:5641-5646.

McLoughlin, R. M., B. J. Jenkins, D. Grail, A. S. Williams, C. A. Fielding, C. R. Parker, M. Ernst, N. Topley, and S. A. Jones. 2005. IL-6 trans-signaling via STAT3 directs T cell infiltration in acute inflammation. Proc. Natl. Acad. Sci. USA 102:9589-9594.

Milne, M. H., D. C. Barrett, J. L. Fitzpatrick, and A. M. Biggs. 2002. Prevalence and aetiology of clinical mastitis on dairy farms in Devon. Vet. Rec. 151:241-243.

Moyes, K. M., J. K. Drackley, D. E. Morin, and L. L. Loor. 2010. Greater expression of TLR2, TLR4, and IL6 due to negative energy balance is associated with lower expression of HLA-DRA and HLA-A in bovine blood neutrophils after intramammary mastitis challenge with Streptococcus uberis. Funct. Integr. Genomics 10:53-61.

National Mastitis Council. 1999. Laboratory Handbook on Bovine Mastitis. National Mastitis Council, Madison, WI.

Oppmann, B., R. Lesley, B. Blom, J. C. Timans, Y. Xu, B. Hunte, F. Vega, N. Yu, J. Wang, K. Singh, F. Zonin, E. Vaisberg, T. Churakova, M. Liu, D. Gorman, J. Wagner, S. Zurawski, Y. Liu, J. S. Abrams, K. W. Moore, D. Rennick, R. de Waal-Malefyt, C. Hannum, J. F. Bazan, and R. A. Kastelein. 2000. Novel p19 protein engages IL-12p40 to form a cytokine, IL-23, with biological activities similar as well as distinct from IL-12. Immunity 13:715-725.

Pedersen, L. H., B. Aalbaek, C. M. Røntved, K. L. Ingvartsen, N. S. Sorensen, P. M. Heegaard, and H. E. Jensen. 2003. Early patho- genesis and inflammatory response in experimental bovine mastitis due to Streptococcus uberis. J. Comp. Pathol. 128:156-164.

Petrovski, K. R., N. B. Williamson, N. Lopez-Villalobos, T. J. Parkinson, and I. G. Tucker. 2011. Culture results from milk samples submitted to veterinary diagnostic laboratories from August 2003 to December 2006 in New Zealand. N. Z. Vet. J. 59:317-322.

Phuektes, P., P. D. Mansell, and G. F. Browning. 2001a. Multiplex polymerase chain reaction assay for simultaneous detection of Staphylococcus aureus and streptococcal causes of bovine mastitis. J. Dairy Sci. 84:1140-1148.

Phuektes, P., P. D. Mansell, R. S. Dyson, N. D. Hooper, J. S. Dick, and G. F. Browning. 2001b. Molecular epidemiology of Streptococcus uberis isolates from dairy cows with mastitis. J. Clin. Microbiol. 39:1460-1466.

Rambeaud, M., R. A. Almeida, and S. P. Oliver. 2004. Growth of Streptococcus uberis in skim milk obtained from Holstein and Jersey dairy cows during different stages of lactation. J. Vet. Med. B. Infect. Dis. Vet. Public Health 51:143-145.

Rambeaud, M., R. A. Almeida, G. M. Pighetti, and S. P. Oliver. 2003. Dynamics of leukocytes and cytokines during experimentally induced Streptococcus uberis mastitis. Vet. Immunol. Immunopathol. 96:193-205.

Riollet, C., P. Rainard, and B. Poutrel. 2000. Cells and cytokines in inflammatory secretions of bovine mammary gland. Adv. Exp. Med. Biol. 480:247-258

Soltys, J., and M. T. Quinn. 1999. Selective recruitment of T-cell subsets to the udder during staphylococcal and streptococcal mastitis: Analysis of lymphocyte subsets and adhesion molecule expression. Infect. Immun. 67:6293-6302.

Stritesky, G. L., N. Yeh, and M. H. Kaplan. 2008. IL-23 pmromotes maintenance but not commitment to the Th17 Lineage. J. Immunol. 181:5948-5955.

Taylor, B. C., R. G. Keefe, J. D. Dellinger, Y. Nakamura, J. S. Cullor, and J. L. Stott. 1997. T cell populations and cytokine expression in milk derived from normal and bacteria-infected bovine mammary glands. Cell. Immunol. 182:68-76.

Thomas, L. H., W. Haider, A. W. Hill, and R. S. Cook. 1994. Pathologic findings of experimentally induced Streptococcus uberis infection in the mammary gland of cows. Am. J. Vet. Res. 55:1723-1728.

Tomita, T., B. Meehan, N. Wongkattiya, J. Malmo, G. Pullinger, J. Leigh, and M. Deighton. 2008. Identification of Streptococcus uberis multilocus sequence types highly associated with mastitis. Appl. Environ. Microbiol. 74:114-124.

Veldhoen, M., R. J. Hocking, C. J. Atkins, R. M. Locksley, and B. Stockinger. 2006. TGF-b in the context of an inflammatory cytokine milieu supports de novo differentiation of IL-17-producing T cells. Immunity 24:179-189.

Weissenbach, M., T. Clahsen, C. Weber, D. Spitzer, D. Wirth, D. Vestweber, P. C. Heinrich, and F. Schaper. 2004. Interleukin-6 is a direct mediator of $\mathrm{T}$ cell migration. Eur. J. Immunol. 34:28952906.

Zadoks, R. N. 2007. Sources and epidemiology of Streptococcus uberis, with special emphasis on mastitis in dairy cattle. CAB Reviews: Perspectives in Agriculture, Veterinary Science, Nutrition and Natural Resources, 2007. CAB International, Wallingford, UK.

Zadoks, R. N., B. E. Gillespie, H. W. Barkema, O. C. Sampimon, S. P. Oliver, and Y. H. Schukken. 2003. Clinical, epidemiological and molecular characteristics of Streptococcus uberis infections in dairy herds. Epidemiol. Infect. 130:335-349.

Zhu, Y. H., P. Q. Liu, X. G. Weng, Z. Y. Zhuge, R. Zhang, J. L. Ma, X. Q. Qiu, R. Q. Li, X. L. Zhang, and J. F. Wang. 2012. Short communication: Pheromonicin-SA affects mRNA expression of toll-like receptors, cytokines, and lactoferrin by Staphylococcus aureus-infected bovine mammary epithelial cells. J. Dairy Sci. 95:759-764. 